\title{
China's Employment Challenges and Strategies after the WTO Accession
}

\author{
Douglas Zhihua Zeng *
}

\begin{abstract}
Although China has made impressive progress in economic development and improving social well-being, it is facing many daunting challenges while transforming toward a knowledge and service-based economy and further opening up to international competition after its WTO accession in the context of knowledge revolution. One of the biggest challenges is how to create 100-300 million new jobs in the coming decade to absorb the millions of laid-offs, rural emigrants and newly added labor force. China has been successful in building high-tech parks and ICT industries, but they are limited in terms of employment generation, while most of the traditional labor-intensive industries are losing competitiveness due to low productivity. In order to combat the unprecedented employment challenge, China must implement a systemic and sustained strategy, which may consist of the following policy thrusts: encouraging the private sector; promoting small and medium enterprises; expanding the service sector; reforming the state-owned enterprises; strengthening the social security system; improving labor market flexibility; and establishing mass retraining programs.
\end{abstract}

Keywords: China; employment; challenges; strategies; WTO accession; productivity; labor market.

\section{World Bank Policy Research Working Paper 3522, February 2005}

The Policy Research Working Paper Series disseminates the findings of work in progress to encourage the exchange of ideas about development issues. An objective of the series is to get the findings out quickly, even if the presentations are less than fully polished. The papers carry the names of the authors and should be cited accordingly. The findings, interpretations, and conclusions expressed in this paper are entirely those of the authors. They do not necessarily represent the view of the World Bank, its Executive Directors, or the countries they represent. Policy Research Working Papers are available online at http://econ.worldbank.org.

\footnotetext{
* The author is an Economist at the World Bank, Washington, D.C. Address: 1818 H St., NW, Washington, D.C., 20433, USA. Email: Zzeng@worldbank.org. He participated in the research and writing of the following World Bank reports - China \& Knowledge Economy: Seizing the $21^{\text {st }}$ Century (2001), and Chile New Economy Study (2003).
} 


\section{Introduction}

China has achieved great success since it undertook reform in 1978. It was one of the world's fastest growing economies in the 1980s and 1990s. According to official statistics, the annual growth rate of real GDP over the past two decades has averaged $9.2 \%$. Its gross national income ranked number six in the world in nominal terms and number two in purchasing power parity (PPP) term in 2001. The per capita GDP quadrupled. The real per capita GDP (PPP adjusted) increased from $\$ 430$ international dollars in 1980 to $\$ 4,475$ international dollars in $2002 .{ }^{1}$ China's total value of imports and exports rose from $\$ 20.6$ billion in 1978 to $\$ 620.8$ billion in 2002, which makes it the $6^{\text {th }}$ largest trading nation in the world. As a result of rapid economic growth, people's standards of living have also been greatly increased. With about one-quarter of a century's reform, China has lifted about 400 million people out of poverty at the $\$ 1$ a day expenditure level. ${ }^{2}$ This is one of the greatest accomplishments in human history.

Along with these developments, the Chinese economy has become increasingly open. The ratio of trade to GDP more than tripled over the past two decades, from $13 \%$ in 1978 to $44 \%$ in 2000 . The percentage increase was the greatest among the major emerging market economies during this period. China has also been one of the largest recipients of foreign direct investment (FDI), which grew from almost zero to 4-5\% of GDP each year in the second half of the 1990s. By May 2000, about 349,537 companies were set up in China by foreign investors from over 180 countries. Total accumulative FDI inflows rose rapidly from $\$ 1.8$ billion in 1983 to $\$ 446.3$ billion in $2002 .^{3}$ All these achievements so far have been unmatchable in the rest of the world.

\section{Daunting Challenges Ahead}

At the same time, China is undertaking a transformation toward knowledge and servicebased economy and undergoing wrenching structural changes. In the context of knowledge revolution, as China is further opening up to international competition after its WTO accession, it faces enhanced pressures to keep up with new knowledge and restructuring economic activities to take advantage of new and better ways of producing goods and services.

Internally, it faces many daunting challenges ahead. By 2002, China's labor force accounts for $25.4 \%$ of the world's total, apparently higher (due to age structure) than the proportion of its population in the world's total $(20.7 \%) .{ }^{4}$ The biggest challenge is: how to productively employ its labor force of over 744 million as it shifts from an agricultural to an industrial and soon a service-based economy, especially how to absorb or reemploy the millions of laid-offs and rural emigrants. It is estimated that China will have to create around 100-300 million new jobs in the coming decade. So it must maintain a high rate of GDP growth, implement an effective employment strategy, and deal with income and

\footnotetext{
${ }^{1}$ World Bank SIMA database, 2003.

2 The World Bank, China: Promoting Growth with Equity, Country Economic Memorandum, Washington, DC, September 2003.

${ }^{3}$ National Bureau of Statistics of China, China Statistical Abstract 2003, China Statistics Press, Beijing.

${ }^{4}$ Author's calculation based on data from the World Bank SIMA database 2003.
} 
regional inequality - as well as serious resource and environmental constraints. The SARS crisis in 2003 also revealed a threat of unbalanced social development.

\section{II.1 The Current Employment Situation}

China's economic growth has not been labor intensive. According to an estimate of the World Bank, in the 1980s, when China's economic growth was $9.3 \%$ a year, employment growth was just 3\% a year, and in the 1990s, when economic growth was about $10.4 \%$, employment growth was only $1.1 \%$. By official statistics, in 2002, there were about 7.7 million unemployed people in the urban areas. ${ }^{5}$ However, the widely perceived effective unemployment rate is about $10 \%$ or even higher, far above the officially registered unemployment level, and, during the late 1990s, each year around 12 million people leave unprofitable formal sector activities (mainly state-owned and collectives). ${ }^{6}$ Xue and Zhong estimated that the urban unemployment rate reached $11.5 \%$ in 2000 and had become a major cause of urban poverty and worsening inequality ${ }^{7}$ (table 1 ).

Table 1. Estimates of China's Urban Unemployment Rate (\%)

\begin{tabular}{llllll}
\hline Year & $\begin{array}{l}\text { Census } \\
\text { data }\end{array}$ & $\begin{array}{l}\text { Survey } \\
\text { data }\end{array}$ & $\begin{array}{l}\text { Official } \\
\text { registered } \\
\text { unemployment }\end{array}$ & $\begin{array}{l}\text { Adjusted unemployment } \\
\text { (official + laid-off } \\
\text { unemployed) }\end{array}$ & $\begin{array}{l}\text { Estimated } \\
\text { unemployment }^{\mathrm{b}}\end{array}$ \\
\hline 1990 & 4.2 & & 2.5 & 2.9 & 4.2 \\
1991 & & 2.3 & 3.2 & 4.7 \\
1992 & & 2.3 & 3.9 & 5.5 \\
1993 & & 2.6 & 3.2 & 7.1 \\
1994 & & & 2.8 & 3.6 & 8.6 \\
1995 & 7.7 & 9.6 & 2.9 & 4.3 & 7.7 \\
1996 & & & 3.0 & 4.8 & 7.3 \\
1997 & & & 3.1 & 5.5 & 9.2 \\
1998 & & & 3.1 & 4.5 & 10.8 \\
1999 & & 11.6 & 3.1 & 6.3 & 12.5 \\
2000 & 11.5 & & 3.1 & 8.1 & 11.5 \\
\hline
\end{tabular}

Source: Population Census in China, 1990, 2000; China Statistic Yearbook, various years, and surveys in 1995 (6,868 households and 21,533 individuals in 11 provinces and 60 cities) and 1999 (4,500 households and 15,904 individuals in 6 provinces and 13 cities) by the Chinese Academy of Social Sciences. Also see Xue \& Zhong, "Unemployment, Poverty and Income Disparity in Urban China", Asian Economic Journal, V17, No. 4, 2003.

Notes: ${ }^{a}$ Laid-off unemployed $=$ laid-off workers - reemployed. In official statistics, the laid-off workers are not counted as unemployed, regardless of their individual situations.

\footnotetext{
${ }^{5}$ National Bureau of Statistics of China, China Statistical Abstract 2003, China Statistics Press, Beijing.

${ }^{6}$ The formal sector refers to state-owned and collectively owned enterprises, plus joint stock and shareholding companies and foreign funded enterprises but excluding township and village enterprises. In a broad definition, they also include non-enterprise units, such as government agencies, institutes, non-profit organizations, etc.

${ }^{7}$ Three surveys conducted by the Chinese Academy of Social Sciences (CASS) in 1988, 1995, and 1999, respectively, show that the Gini coefficient for the urban area rose from 0.185 in 1988 to 0.225 in 1995 and 0.256 in 1999 . The percentage increase was $22 \%$ for the period $1988-1995,14 \%$ for the period $1995-1999$ and $38 \%$ for the whole period $1988-1999$. The 1999 survey also shows that the poverty rate was $13.2 \%$ for households with unemployed people and only $2.8 \%$ for households without unemployed people. See Xue \& Zhong (2003).
} 
${ }^{\mathrm{b}}$ Estimation by using the census data as benchmarks and link them with the adjusted unemployment data. See Xue \& Zhong (2003) for details.

Between 1996 and 2001, the number of urban and township workers fell from 149 million to 108 million, a net reduction of 41 million or $28 \%{ }^{8}$ This includes a main drop of 52.5 million in state-owned and urban collectives and an increase of 12 million in the emerging formal private sector (joint stock and shareholding companies and foreignfunded enterprises). Meanwhile, at the same time period, the employment in the urban informal private and self-employed sectors enjoyed a 13.3 million, or $57 \%$ increase. The number of rural emigrants is also rapidly increasing. Current estimates of the number of migrant workers fluctuate between 40 and 80 million, which is about 6-10 percent of the total labor force. ${ }^{9}$ According to the survey data from the National Statistics Bureau, from 1997-2000, the share of rural migrant labor as a percentage of the total rural labor force increased from $18.1 \%$ to $23.6 \%$, i.e., from 83.2 million to 113.4 million, increasing 10.07 million or $10.8 \%$ annually on average.

With the "revitalizing China with science and education" policy, China has achieved great success in several new industries in the past five to seven years, particularly high technology and ICTs. China has also been successful in modernizing and restructuring the economic base of coastal cities through the "special economic zone" approach. However, these new industries are limited in terms of employment-generating capability. In the late 1990s employment in the 53 designated high-technology parks (mostly in the coastal areas) had reached only 2.2 million people, even though several parks have enjoyed rapid and sustained growth (annual growth in sales of 50\%). ${ }^{10}$

Electronics and telecommunications industries, despite considerable efforts toward their development, do not generate many new jobs. ${ }^{11}$ Altogether these industries' share reached $8.7 \%$ of the manufacturing total labor force in 2000, up from $7.3 \%$ in 1994 (table 2 ). On the other hand, the labor-intensive light industries employed more than $30 \%$ of the labor force in 2000. Growing steadily, the traditional basic industries-such as metal products, chemicals, and machinery, which have not received priority attention from the authorities_-had about $57 \%$ of the labor force in 2000 .

Table 2. Number and Share of Workers in Manufacturing Industries (1994-2000) ${ }^{a}$

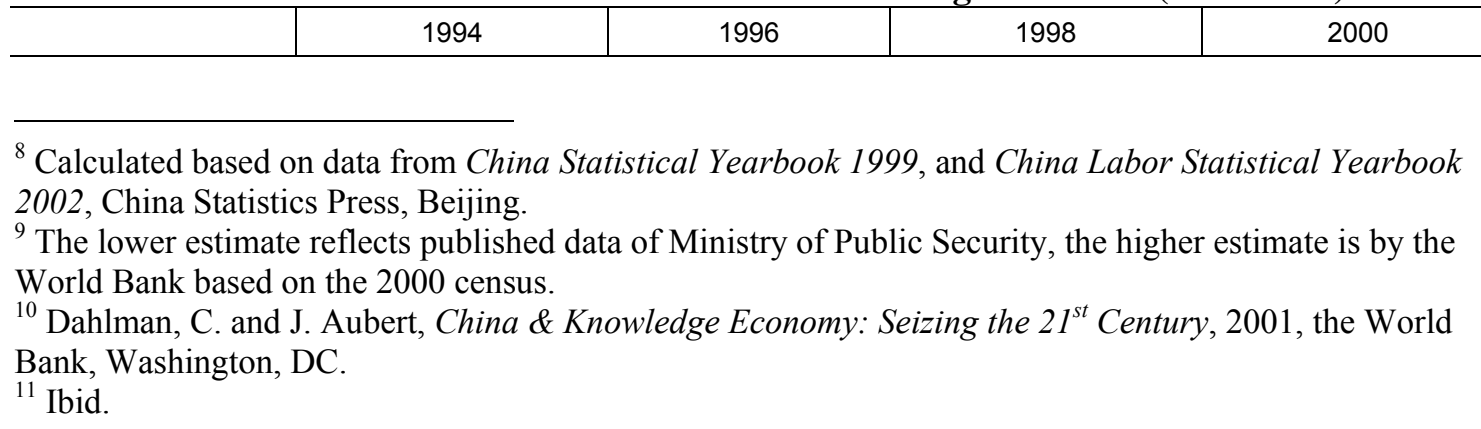




\begin{tabular}{l|c|c|c|c|c|c|c|c}
\hline \multicolumn{1}{c|}{ Category } & $\begin{array}{c}\text { Number of } \\
\text { workers } \\
(1,000)\end{array}$ & $\begin{array}{c}\text { Share } \\
\text { (percent) }\end{array}$ & $\begin{array}{c}\text { Number of } \\
\text { workers } \\
(1,000)\end{array}$ & $\begin{array}{c}\text { Share } \\
\text { (percent) }\end{array}$ & $\begin{array}{c}\text { Number of } \\
\text { workers } \\
(1,000)\end{array}$ & $\begin{array}{c}\text { Share } \\
\text { (percent) }\end{array}$ & $\begin{array}{c}\text { Number of } \\
\text { workers } \\
(1,000)\end{array}$ & $\begin{array}{c}\text { Share } \\
\text { (percent) }\end{array}$ \\
\hline Manufacturing industry & 54,320 & 100 & 52,930 & 100 & 37,690 & 100 & 32,400 & 100 \\
Light industry & 18,060 & 33.25 & 17,280 & 32.65 & 11,650 & 30.91 & 9,950 & 30.71 \\
Chemical products & 7,960 & 14.65 & 8,140 & 15.38 & 6,220 & 16.5 & 5,350 & 16.51 \\
Metal products & 10,440 & 19.22 & 10,260 & 19.38 & 7,430 & 19.71 & 6,380 & 19.69 \\
Machinery & 10,810 & 19.9 & 10,560 & 19.95 & 7,510 & 19.93 & 6,290 & 19.41 \\
Electronics and & 3,960 & 7.29 & 3,990 & 7.54 & 3,040 & 8.07 & 2,830 & 8.73 \\
telecommunications & 3,610 & 6.65 & 2,110 & 3.99 & 1,390 & 3.69 & 1,220 & 3.77 \\
Miscellaneous & & & & & & & &
\end{tabular}

a. Includes only state-owned industrial enterprises and non-state enterprises with annual sales greater than 5 million yuan).

Note: Industries were grouped according to six categories: light industry, chemical products, metal products, machinery and transport equipment, electronic and telecommunications equipment, and miscellaneous.

Source: National Bureau of Statistics: China Statistical Yearbook 2002.

Overall, China's current labor market manifests the following characteristics. First, while the state sector is shedding employment in large numbers, the non-state sector, especially the private sector, is enjoying a rapid increase in employment. This is the so-called "dual labor market structure", where two sectors are competing for skilled workers. ${ }^{12}$ Second, employment has been shifting from primary and secondary sectors to the tertiary sector. One notable trend is that an increasing number of rural laborers are migrating to urban areas to work mostly in service activities, such as cleaning, maintenance and repair, construction, restaurants, and so on. Third, a large portion of laid-off workers become permanently unemployed. It is increasingly difficult for these workers to be re-employed in conditions of labor over-supply. According to an official statistical bulletin, in the first half of 2001, out of 7.69 million laid-off workers, only 0.79 million succeeded in obtaining other jobs, and the re-employment rate was only $10 \%$. ${ }^{13}$ Fourth, with economic development and urbanization, there is an increasing number of people displaced by extensive land requisition in peri-urban areas. Those displaced include farmers, shopkeepers, enterprise employees, and migrants. For example, in Shanghai, for every hectare of farmland requisitioned, between 15-30 people have to be given new nonagricultural employment. ${ }^{14}$ The resettlement of these people poses another big challenge to the government and the labor market.

\section{II.2 The Employment Impact of the WTO Accession}

Estimates of the employment impact vary widely, depending on the assumptions one makes about the employment elasticity of output, the extent to which imported goods will

\footnotetext{
${ }^{12}$ Cai, Fang, "The Transformation of the Employment Structure in a Dual Labor Market", Social Sciences in China, Vol. 20, No. 3, Autumn 1999.

${ }^{13}$ Bhalla, A. S. and S. Qiu, "China's Accession to WTO: Its Impact on Chinese Employment", UNCTD discussion paper, No. 163, November 2002.

${ }^{14}$ Meikle, Sheilah and Y. Zhu, "Employment for Displacees in the Socialist Market Economy of China", from Cernea, Michael M. and C. McDowell ed., Risks and Reconstruction: Experiences of Resettlers and Refugees, the World Bank, Washington, D.C., 2000.
} 
replace domestic goods and the magnitude of bankruptcies of inefficient state and nonstate firms. Estimates of the employment elasticity by sector and time period show that it has declined in primary and secondary sectors (table 3), but is generally higher in the tertiary sector, which is likely to absorb the bulk of displaced labor as a result of the accession.

Table 3. Employment Elasticity of Output (in periods)

\begin{tabular}{c|c|c|c}
\hline Period & Primary & Secondary & Tertiary \\
\hline $1955-59$ & -9.64 & 0.57 & 1.83 \\
$1960-64$ & 2.70 & -0.15 & 0.99 \\
$1965-69$ & 1.10 & 0.12 & 2.32 \\
$1970-74$ & 0.50 & 1.35 & 0.39 \\
$1975-79$ & -0.05 & -0.19 & 3.98 \\
$1980-84$ & -0.09 & 0.89 & 0.70 \\
$1985-89$ & 0.52 & 0.29 & 0.43 \\
$1990-94$ & 0.22 & 1.00 & 2.00 \\
$1995-99$ & -0.07 & 0.09 & 0.51 \\
\hline
\end{tabular}

Note: Elasticity in each period is an average of annual figures.

Source: Calculated based on the data from the China Statistical Yearbook, and China Labor Statistical Yearbook, various years. Bhalla, A. S., and S. Qiu, 2002.

Generally speaking, a negative impact of the accession on employment will be felt through import competition and the resulting closure of inefficient domestic firms, especially SOEs and collectives. However, this impact will not be evenly spread across sectors and industries. Most researchers believe that the potential for employment growth is minimal or negative in such sectors as agriculture, automobiles, machinery and instruments. Some estimate that employment in the agricultural sector will be reduced by 9.66 million (or 3.6 percent of the current total), automobiles 4.98 million (14.5 percent of the total), and machinery and instrument 5.82 million (2.5 per cent of the total) in seven years after the accession. ${ }^{15}$ Ianchovichina and Martin assessed the changes in output and employment in selected Chinese industries due to WTO accession for the period after 2001. They estimate that an employment gain might occur in the following industries: plant based fibers, livestock and meat, clothing, light manufacturing and electronics. On the other hand, employment will decline in foodgrains, feedgrains, vegetables and fruits, oilseeds, beverages and tobacco, petrochemicals, metals, automobiles, communication, and commercial services, etc. Furthermore, for the period of 2001-2007, approximately 6 million farm workers will leave their farm jobs as a result of WTO accession reform after 2001 to pursue employment in non-agricultural sectors. ${ }^{16}$ Bhalla and Qiu also think that China has no comparative advantage in foodgrains, feedgrains, and oilseeds because they are land-intensive crops and China's domestic prices for these commodities are much higher than world prices. But they think in other primary export products including meat, fishery products, vegetables, fruits and tobacco, China will still maintain a comparative advantage as these products do not need much land and can utilize redundant labor. ${ }^{17}$ They also presented a general picture of WTO impact on the Chinese industry by a matrix of industry ownership, openness, technology

\footnotetext{
${ }^{15}$ Beijing Evening News, 18 November 1999.

${ }^{16}$ Ianchovichina, Elena, W. Martin, Economic Impacts of China's Accession to the World Trade Organization, World Bank Working Paper, the World Bank, May 2003.

${ }^{17}$ Bhalla, A. S. and S. Qiu, "China's Accession to WTO: Its Impact on Chinese Employment", UNCTD discussion paper, No. 163, November 2002.
} 
level and entry barriers (table 4). Yao (2002) believes that the WTO accession will likely accelerate the negative impact on rural employment and income, at least in the short and medium terms. ${ }^{18}$

Table 4. Matrix of the Impact of WTO Accession on Chinese Industry

\begin{tabular}{|c|c|c|c|c|}
\hline Market structure & $\begin{array}{l}\text { Ownership } \\
\text { structure }\end{array}$ & $\begin{array}{l}\text { Entry barriers (tariff } \\
\text { or non-tariff) }\end{array}$ & $\begin{array}{l}\text { Government } \\
\text { subsidy }\end{array}$ & $\begin{array}{l}\text { Status \& impact of the } \\
\text { accession }\end{array}$ \\
\hline $\begin{array}{l}\text { Globally } \\
\text { integrated/competitive: } \\
\text { Competition in both } \\
\text { global and domestic } \\
\text { markets (e.g., } \\
\text { shipbuilding, textiles, } \\
\text { clothing, electronics) }\end{array}$ & $\begin{array}{l}\text { State- } \\
\text { owned, } \\
\text { collective, } \\
\text { TVEs, } \\
\text { joint } \\
\text { ventures, } \\
\text { or private }\end{array}$ & Low or zero & Low or zero & $\begin{array}{l}\text { (a) Economic: } \\
\text { - Higher efficiency; } \\
\text { - Better market access. } \\
\text { (b) Social: } \\
\text { - Increase in employment } \\
\text { through increase in } \\
\text { exports. }\end{array}$ \\
\hline $\begin{array}{l}\text { Segmented/protected: } \\
\text { Domestic and export } \\
\text { markets are segmented } \\
\text { as the former is } \\
\text { protected (e.g., } \\
\text { machinery and } \\
\text { chemicals, and } \\
\text { automobiles) }\end{array}$ & $\begin{array}{l}\text { State- } \\
\text { owned, } \\
\text { collective, } \\
\text { TVEs, } \\
\text { joint } \\
\text { ventures } \\
\text { or private }\end{array}$ & Medium or high & $\begin{array}{l}\text { Low or } \\
\text { medium }\end{array}$ & $\begin{array}{l}\text { (a) Economic: } \\
\text { - Improved efficiency; } \\
\text { - Better market access. } \\
\text { (b) Social: } \\
\text { Loss of employment in } \\
\text { inefficient enterprises; } \\
\text { increase in employment in } \\
\text { efficient ones. }\end{array}$ \\
\hline $\begin{array}{l}\text { Insulated: Only } \\
\text { domestic competition, } \\
\text { mostly closed to } \\
\text { foreign entry (e.g., } \\
\text { telecom, banking \& } \\
\text { financial services, and } \\
\text { petrochemicals) }\end{array}$ & $\begin{array}{l}\text { State- } \\
\text { owned }\end{array}$ & High & $\begin{array}{l}\text { Medium or } \\
\text { high }\end{array}$ & $\begin{array}{l}\text { (a) Economic: } \\
\text { - Scope for raising } \\
\text { efficiency; } \\
\text { - Better market access. } \\
\text { (b) Social: loss in } \\
\text { employment due to import } \\
\text { competition; increase in } \\
\text { employment through better } \\
\text { market access. }\end{array}$ \\
\hline
\end{tabular}

Source: Bhalla, A. S., and S. Qiu, 2002.

Despite the different effects on specific industries, the overall employment situation after the WTO accession will be very challenging. According to the author's estimation, China's labor force will grow by 80 million people over the next decade-from 742 million in 2000 to 822 million in 2010. A World Bank study (which the author participated in) shows that, considering the new entrants, the continuing employment shake-offs from agriculture, state-owned enterprises (SOEs), and township and village enterprises (TVEs), as well as the displaced and early retirees, it is expected that the Chinese economy needs to create about 8 to 9 million new employment opportunities annually. ${ }^{19}$ This is much higher than China's current job-creation capacity. Furthermore, other projections estimate the number of new jobs to be created at a much higher level -

\footnotetext{
${ }^{18}$ Yao, Shujie, "China's Rural Economy in the First Decade of the 21st Century: Problems and Growth Constraints”, China Economic Review, V13, 2002, pp. 354-360.

${ }^{19}$ Dahlman, C. and J. Aubert, China \& Knowledge Economy: Seizing the $21^{\text {st }}$ Century, 2001, the World Bank, Washington, DC.
} 
20 to 30 million per year for the next decade, counting the potential lay-offs of half of the people currently working in agriculture, SOEs, and TVEs. ${ }^{20}$

Though different in estimates, these projections show that a considerable number of new jobs will have to be created - taking a medium estimation, about 100 million (mostly in urban areas) in the next ten years. The high technology and advanced manufacturing sectors will not be able to add more than 20-30 million new jobs. Therefore, the main sources of new job creation will continue to be labor-intensive industries, such as textiles (where China is projected to increase its global market share from 20 to $40 \%$ by 2010) and the service industries (including tourism, building and construction, etc.).

To dramatically increase employment in the service sector would be no easy job. Most of these new jobs will be in informal service sectors and basic infrastructure services (construction, transport, telecommunications), tourism, retailing, and commerce. Another important source for generating employment would be small private high-value business services (such as marketing, branding, consulting, management, financial, logistics, distribution) and other professional services. These are more intangible and knowledgeintensive sectors and traditionally underdeveloped in China, but they are the critical components for a knowledge-based economy. ${ }^{21}$ If China wants to upgrade its industrial structure and greatly enhance its international competitiveness, these areas have to be well developed.

In sum, although the WTO accession will certainly help generate some additional employment by attracting more foreign direct investment (FDI), boosting certain industries, and expanding related services, considering the poor productivity in most industries and sectors in China (see the following analysis) and the fierce international competition after further opening up, the negative employment impact of the accession would be far greater than its positive effect, especially in the short run.

\section{II.3 Weak Productivities - An International Comparison}

In China, the majority of the labor force is still in agriculture, traditional low and medium technology industries, and low skill services. These sectors are normally not performing very well, which can be seen from their poor productivity rates and a surprising decline in the share of services in overall GDP, despite rising prices. ${ }^{22}$ One of the reasons is the lack of new technologies and management efficiency. Thus, it is crucial to disseminate new technologies and advanced management practices throughout the economy.

Figure 1 Agriculture Productivity versus GDP/Capita, for the Period 1979-81

\footnotetext{
${ }^{20}$ See 1999 Chinese Academy of Social Science report by Feng Nanrui. Note also that the tenth 5 Year Plan estimates that 40 million rural laborers will have to find jobs outside of the agriculture sector.

${ }^{21}$ Dahlman, C. and J. Aubert, China \& Knowledge Economy: Seizing the $21^{\text {st }}$ Century, 2001, the World Bank, Washington, DC.

${ }^{22}$ See Hwa (2000) for data and an analysis of the underdevelopment of the service sector in China.
} 


\section{Compared to 1999-2001 (Value Added per Worker in 1995 US\$)}

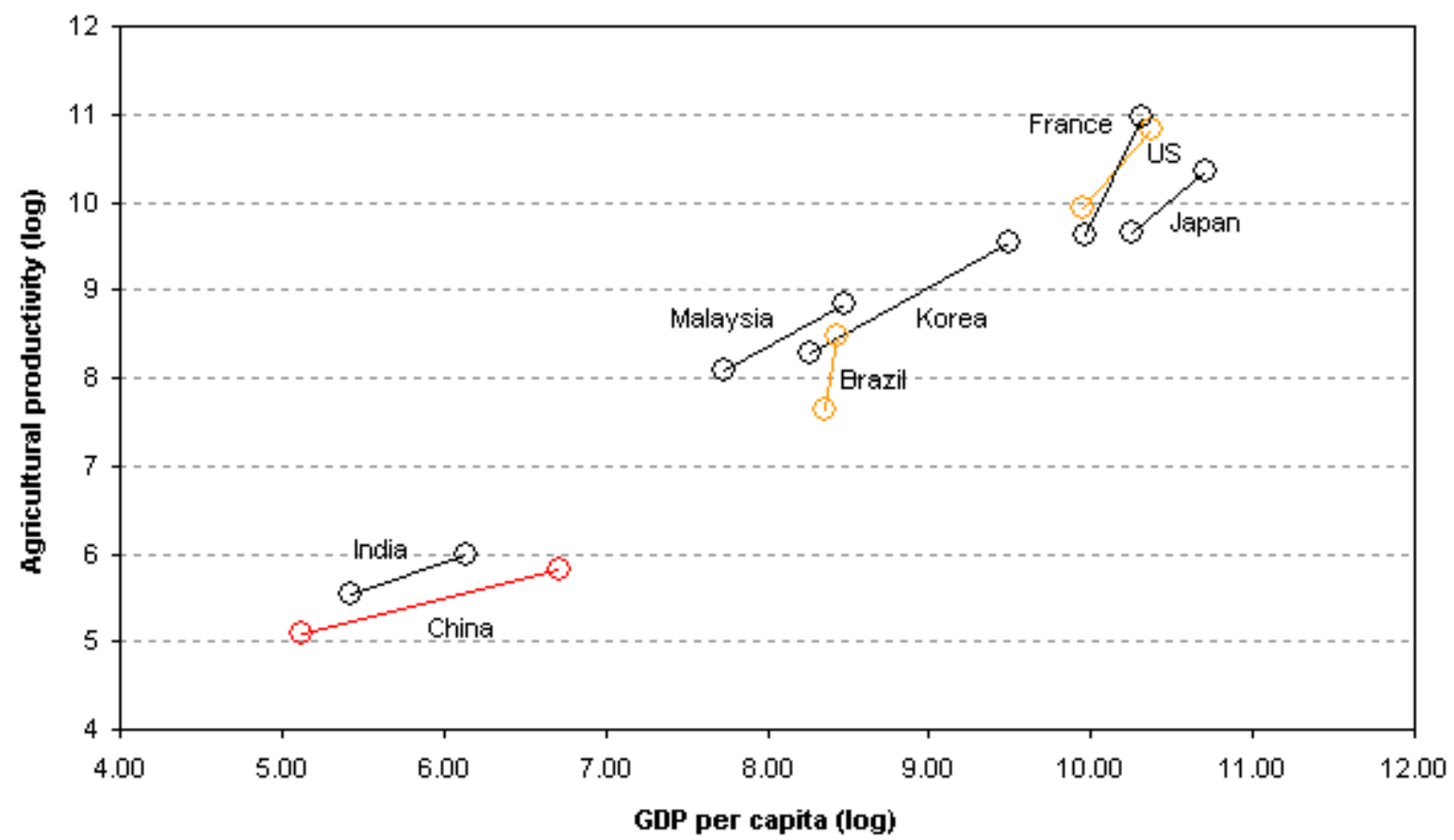

Note: Data should be interpreted cautiously because international productivity comparisons are fraught with problems, including inconsistent data sources and definitions and biases caused by currency devaluations or appreciations.

Source: Author's analysis based on data from the World Bank Development Indicators 2003.

A comparison of China's labor productivity with advanced economies and other developing economies shows that China is lagging behind and needs to make great progress in all sectors (figure 1). ${ }^{23}$ According to the World Bank figures, Agricultural productivity per worker in China is $75 \%$ of that in India and only $0.8 \%$ of that in France or the United States. The IMD (International Institute for Management Development) data also show the sharp contrasts between China and developed countries and even with some developing countries (table 5). Only the cereal yields per hectare in China are not far from U.S. yields and are much higher than those in Brazil, Malaysia, and India (table 6 ). This suggests that to some extent the productivity problem in the Chinese agricultural sector is one of surplus labor and land tenancy - too many people (many of them are redundant) working on the segmented pieces of lands under the household responsibility system, making it unsuitable for large machine-based production—rather than technical incompetence (table 7). According to Rozelle et al., the average size of a farm is only about 1.2 acres, and each farm typically has multiple plots. ${ }^{24}$ The arable land per capita has experienced a huge decrease. Based on J. Knight \& L. Song's study, over the commune and planning period (1952-78), the area under cultivation rose by only $3 \%$, and cultivated land per rural worker fell by more than one-half. Over the period of economic

\footnotetext{
${ }^{23}$ Dahlman, C. and J. Aubert, China \& Knowledge Economy: Seizing the $21^{\text {st }}$ Century, 2001, the World Bank, Washington, DC.

${ }^{24}$ Rozelle, Scott, Jikun Huang and L. Zhang, "Emerging Markets, Evolving Institutions, and the New Opportunities for Growth in China's Rural Economy”, China Economic Review, V13, 2002, pp. $345-353$.
} 
reform (1978-2000) this trend continued, and the fall exceeded one-third. ${ }^{25}$ Yao also estimated that, between 1953 and 1989, per capita arable land and crop area declined, respectively, by $2.08 \%$ and $1.69 \%$ per year. ${ }^{26}$ Should more rural labor move out of the agricultural sector and more machinery be used in farming, China's agricultural productivity could expect a major improvement. ${ }^{27}$ However, considering the current industrial structure and land tenancy system, this would be a very difficult and slow process. Furthermore, based on 2000 data, China's manufacturing labor productivity was only $92 \%$ of that in India and less than $5 \%$ of that in Brazil, France, Japan, and the United States (figure 2).

Table 5. Productivity Comparison in Agriculture, Industry, and Services (1999) (Related GDP per person employed in industry, US\$)

\begin{tabular}{l|l|l|l|l|l|l|l|l|l|l|l}
\hline & China & U.S. & U.K. & $\begin{array}{l}\text { Germa } \\
\text { ny }\end{array}$ & Japan & Finland & Korea & $\begin{array}{l}\text { Malays } \\
\text { ia }\end{array}$ & Brazil & Chile & $\begin{array}{l}\text { Thailan } \\
\text { d }\end{array}$ \\
\hline Agriculture & 512 & 53657 & 62117 & 41332 & 25902 & 34835 & 10439 & 3733 & 3795 & 7059 & 885 \\
Industry & 2954 & 81077 & 60168 & 64556 & 80860 & 65977 & 32138 & 13534 & 19827 & 18244 & 8506 \\
Services & 1751 & 66494 & 48329 & 58205 & 64294 & 52199 & 16959 & 7365 & 13771 & 12349 & 5773 \\
\hline
\end{tabular}

Source: IMD, The World Competitiveness Yearbook 2000, Lausanne, Switzerland, pp461-463.

Table 6. Cereal Yields (Selected Countries)

(kilograms per hectare)

\begin{tabular}{l|l|l|l|l|l|l|l|l}
\hline Year & China & $\begin{array}{l}\text { United } \\
\text { States }\end{array}$ & France & Japan & India & S Korea & Malaysia & Brazil \\
\hline $1976-81$ & 3,027 & 4,151 & 4,700 & 5,252 & 1,324 & 4,986 & 2,828 & 1,496 \\
$1999-2001$ & 4,869 & 5,824 & 7,088 & 6,147 & 2,321 & 6,500 & 3,075 & 2,825 \\
\hline
\end{tabular}

Source: The World Bank, World Development Indicators 2003, pp. 128-131.

Table 7. Rural Labor Density and Agricultural Machinery Comparison (1999/2000)

\footnotetext{
${ }^{25}$ Knight, John and L. Song, "Chinese Peasant Choices: Migration, Rural Industry or Farming”, Oxford Development Studies, V31, No.2, June 2003.

${ }^{26}$ Yao, Shujie, "Agriculture's Role in Economic Development: The Case of China”, from Cook, Sarah, Shujie Yao and J. Zhuang, ed., The Chinese Economy Under Transition, MacMillan (London) and St. Martin's (New York), 2000. Also Yao, S., Economic Reforms and Grain Production in China, MacMillan, London, 1994.

${ }^{27}$ A household survey in Zouping County, Shandong Province, collected between 1990 and 1994, shows that, when controlling for household off-farm employment, the effect of per capita land on incomes increases by approximately $10 \%$. This result may be due to the effect of moving labor out of agriculture. As labors move off the land, other resources may be more efficiently allocated and the returns to land also increase. Controlling for employment, a one $m u$ (Chinese measure, equaling $1 / 15^{\text {th }}$ of a hectare) increase in per capita land leads to a 36\% increase in per capita household income. See Cook, S., "Employment, Enterprise and Inequality", from Cook, Sarah, Shujie Yao and J. Zhuang, ed., The Chinese Economy Under Transition, MacMillan (London) and St. Martin's (New York), 2000.
} 


\begin{tabular}{l|cccccccc}
\hline & China & $\begin{array}{c}\text { United } \\
\text { States }\end{array}$ & France & Japan & India & S Korea & Malaysia & Brazil \\
\hline $\begin{array}{l}\text { No. of rural labors } \\
\text { per hectare of arable } \\
\text { land (1999)* }\end{array}$ & 4.11 & 0.02 & 0.05 & 0.62 & 1.63 & 1.39 & 0.97 & 0.25 \\
\hline $\begin{array}{l}\text { Agricultural } \\
\text { machinery per 1,000 } \\
\begin{array}{l}\text { agricultural workers } \\
(2000)\end{array}\end{array}$ & 0.00 & 1.56 & 1.35 & 0.73 & 0.01 & 0.07 & 0.02 & 0.06 \\
\hline
\end{tabular}

Source: World Bank SIMA database, 2003.

* Author's calculation based on the same database.

Figure 2 Manufacturing Productivity versus GDP/Capita, for Period 1980-84 Compared to 1995-99 (Average Nominal US \$)

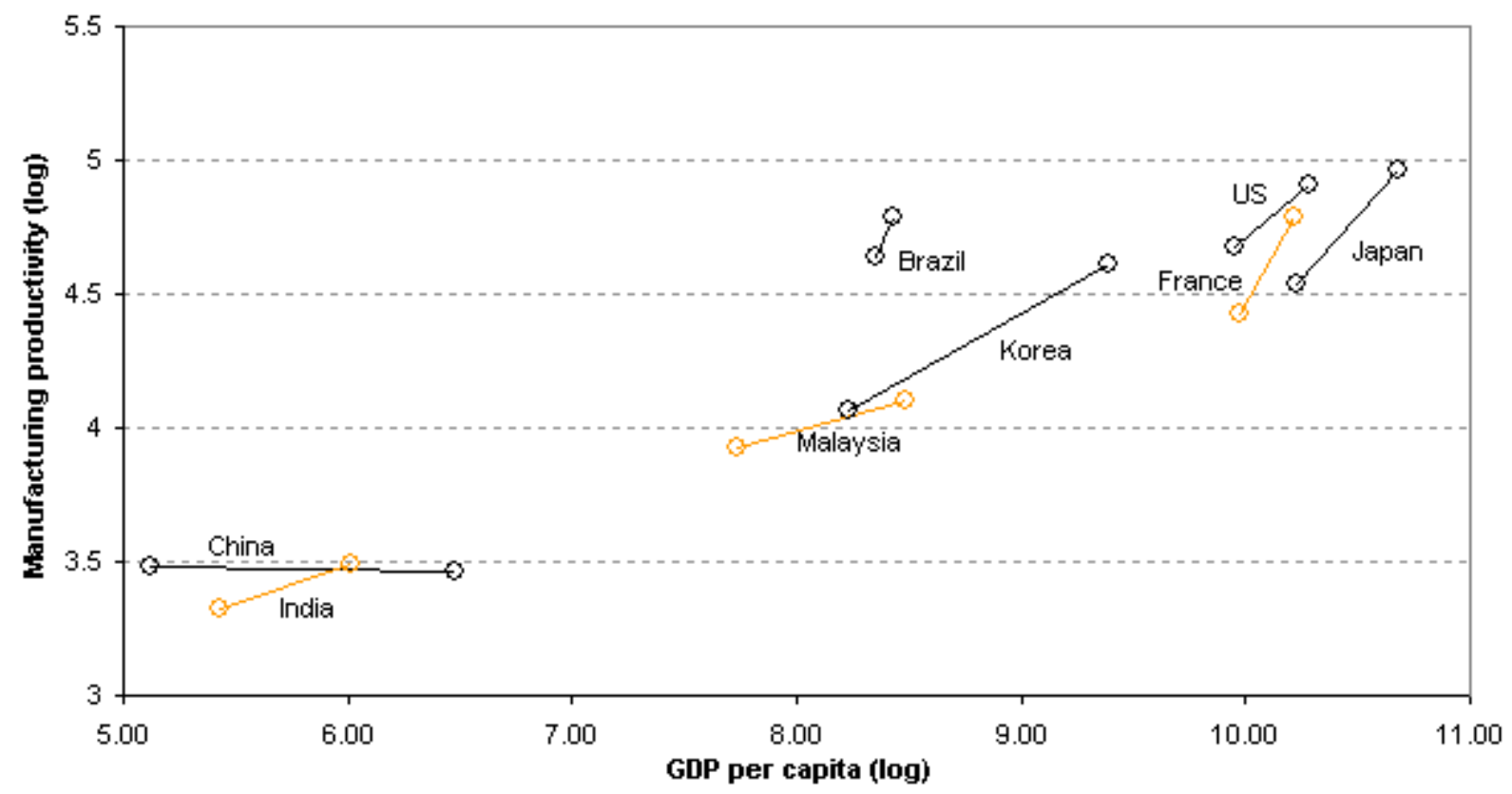

Source: Author's analysis based on data from the World Bank Development Indicators 2003.

According to Hwa's research, China's labor productivity gains experienced a jump in the early 1990s, but then slowed down in all sectors of the economy (figure 3). ${ }^{28}$ Labor productivity is much lower in agriculture, services, and construction sectors than in industry, implying excessive labor and low capital investment in these sectors.

Figure 3 China's Labor Productivity , 1987-97 (Yuan per Person)

\footnotetext{
${ }^{28}$ Hwa, E. C. 2000. "China: Service Sector Development and Competitiveness.” Mimeo. World Bank, Washington, D.C.
} 


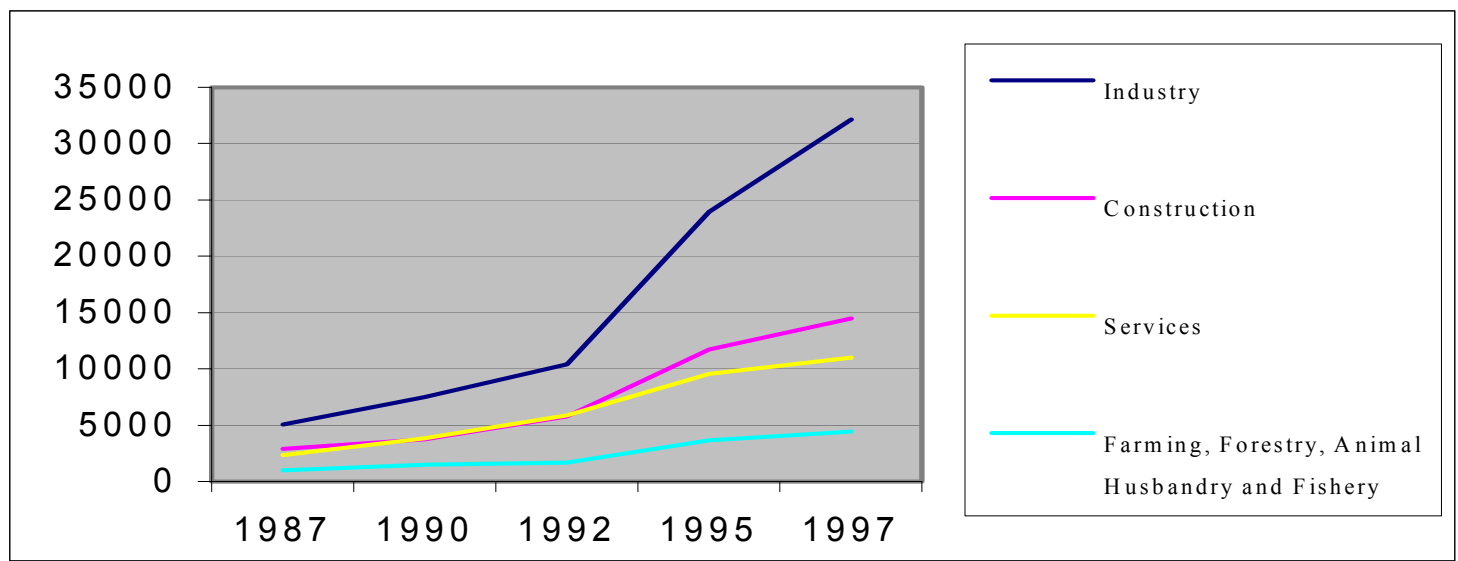

Source: Hwa 2000 and World Bank staff calculations.

Considering China's severe employment situation, to keep the current labor-intensive industries viable would be crucial to prevent more people from being laid-off. However, the huge productivity gaps between China and international competitors and the enhanced competition after China's accession to the World Trade Organization would make it very difficult. Although the liberalization process will be gradual with time for adjustment (box 1), the Chinese economy will unavoidably face strong international competitive pressures, forcing it to restructure and optimize itself according to its international comparative advantage.

\section{Box 1 Accession to the World Trade Organization Entails Important Changes}

The commitment of China to the World Trade Organization on a set of trade reforms that will have far-reaching impact on its economy:

- $\quad$ Eliminating the import quota by 2006.

- $\quad$ Eliminating import tariffs on computers, semiconductors, and related products by 2005.

- Reducing the import tariff on agricultural products from $22 \%$ to $17.5 \%$.

- Reducing the import tariff on industrial products from $24 . \%$ to $9.4 \%$.

- $\quad$ Reducing the import tariff on vehicles from $100 \%$ to $25 \%$ by 2006 .

- Reducing the import tariff on vehicle parts by $10 \%$.

- Allowing up to 50\% foreign ownership of telecommunications and insurance.

- Allowing importers to own domestic distribution networks.

- Allowing full market access for foreign banks within five years of accession (foreign banks will be able to conduct local currency business with Chinese enterprises two years after accession). 


\section{China's Employment Strategies After WTO Accession}

Faced with the serious employment problems compounded by its entry into the WTO, China has to take effective steps to deal with the challenges. On one hand, China must fully expand the development of the private sector, especially the small and medium enterprises, promote the service industries, and reform the overly burdened SOEs; on the other hand, it must establish a nation-wide social safety net, improve the labor market, and provide mass on-the-job training or reemployment and re-skilling trainings.

\section{III.1 Encouraging the Private Sector}

China is now undertaking a dramatic transformation from a traditionally planned economy to a market-based economy. Although China's economic growth has gained great success by first restructuring agriculture and then moving people out of agriculture and into industry, the traditional industrial enterprises such as state-owned enterprises (SOEs), township and village enterprises (TVEs) are losing steam. The number of workers in state-owned units ${ }^{29}$ plunged from 112 million in 1995 to 71.6 million in 2002, and those in collective urban units from 32 million to 11.2 million, a decline of $32 \%$ and $65 \%$, respectively. Most of the losses are from the SOEs or collective-owned enterprises, though the exact figures are hard to obtain. Meanwhile, the number of employees in the private enterprises (including enterprises fully registered as private plus some sort of shareholding and joint ownership companies-rose from 13 million to 42 million (more than tripled), and the those in foreign plus Hong Kong, Macao \& Taiwan enterprises increased from 5.1 million to 6.7 million, or $31 \% .{ }^{30}$ The employment elasticity of the self-employed and private enterprises in general is considerably higher that that of enterprises of other ownerships. ${ }^{31}$

The emergence of the domestic private sector is the most important result of the reform process in China and the domestic private sector is increasingly important in contributing to output and the creation of new jobs. The output of the private sector has grown an average of 71 percent per year since 1980, and non-state employment has risen an average of 41 percent per year. According to an IFC study, privately owned enterprises currently account for 33 percent of the Chinese gross domestic product, compared to the state-sector's 37 percent. However, including privately owned agribusiness brings the total to 51 percent; and with the contribution of collective enterprises, which are in various intermediate forms of non-state ownership, the total non-state contribution to China's GDP amounts to some 62 percent. ${ }^{32}$ As a result, the private sector has become the major source of reemployment or job creation. This point is demonstrated by the fact

\footnotetext{
29 According to the China Statistic Yearbook, the "units" not only include state-owned enterprises (SOEs), but also the state-owned social services (public facilities, community and recreation services, etc.), education, public health, R\&D institutions, and government/party agencies, etc. The same concept applies to the "collective units".

${ }^{30}$ Based on data from China Statistical Yearbook, 1999, 2002, China Statistical Press, Beijing.

${ }^{31}$ Lu, Ming, et al., "Employment Restructuring during China's Economic Transition”, Monthly Labor Review, Vol. 125, No. 8, August 2002.

32 IFC: China's Emerging Private Enterprises: Prospects for the New Century, 2000, Washington, DC, USA.
} 
that the unemployment rate is high in areas where the private economy is underdeveloped, whereas it is low in those areas with a flourishing private economy. ${ }^{33}$

Table 8. Structure of Employment, by Type of Ownership in China (1980-2000, in Millions of Workers)

\begin{tabular}{|c|c|c|c|c|c|c|c|c|c|c|c|}
\hline & $\begin{array}{l}\text { Total } \\
\text { Emplo } \\
\text { yment }\end{array}$ & $\begin{array}{l}\text { Urban } \\
\text { Employ } \\
\text { ment }\end{array}$ & $\begin{array}{l}\text { State- } \\
\text { owned } \\
\text { units }^{\text {a }}\end{array}$ & $\begin{array}{l}\text { Collective } \\
\text { units a }\end{array}$ & Private $^{b}$ & Foreign & $\begin{array}{l}\text { Self- } \\
\text { employed }\end{array}$ & $\begin{array}{l}\text { Rural } \\
\text { Emplo } \\
\text { yment }\end{array}$ & TVE & Private & $\begin{array}{l}\text { Self- } \\
\text { employed }\end{array}$ \\
\hline 1980 & 423.6 & 105.3 & 80.2 & 24.3 & 0.4 &.. & 0.8 & 318.4 & 30.0 &.. &. \\
\hline 1990 & 693.1 & 170.4 & 103.5 & 35.5 & 1.5 & 0.7 & 6.1 & 471.1 & 92.7 & 1.1 & 14.9 \\
\hline 1995 & 679.5 & 190.4 & 112.6 & 31.5 & 8.6 & 5.1 & 15.6 & 490.3 & 128.6 & 4.7 & 30.5 \\
\hline
\end{tabular}

Notes: ${ }^{a}$ The "units" not only include state-owned or collective-owned enterprises, but also the state or collective-owned social services (public facilities, community and recreation services, etc.), education, public health, R\&D institutions, and government/party agencies, etc.

${ }^{\mathrm{b}}$ Under this heading are companies classified as private enterprises (normally informal), plus those classified as joint-owned units, limited shareholding corporations, limited liability corporations, and shareholding corporations. The last two categories actually appear only from 1998 on. Note that in China, an important amount of employees are not registered in any official category (floating employment). Source: China Statistical Yearbook 2002, calculated from table 5-4.

Empirical studies also show that the private sector has achieved significantly greater productivity gains and R\&D efficiencies and has contributed more to economic growth than all other sectors. ${ }^{34}$ Wei, Zuobao, et al. studied the pre- and post-privatization financial and operating performance of 208 firms privatized during 1990-97. Results show significant improvements in real output, real assets, and sales efficiency, but no significant change in profitability. A further performance comparison between 41 fully state-owned firms and 41 privatized firms for the period of 1994-1999 shows that privatized firms experienced significant improvements in profitability, employment, and sales efficiency, especially those with over $50 \%$ voting control conveyed to private investors, while the SOEs experienced declines (see table 9). ${ }^{35}$

\footnotetext{
${ }^{33}$ Lee, Hong Yung, "Xiagang, The Chinese Style of Laying Off Workers", Asian Survey, V40, No. 6, November/December 2000.

${ }^{34}$ Zhang, Anming, et al., "A Study of the R\&D Efficiency and Productivity of Chinese Firms", Journal of Comparative Economics, V31, 2003, pp. 444-464; and Lo, V. and X. Tian, "Property Rights, Productivity Gains and Economic Growth: the Chinese Experience”, Post-Communist Economies, V14, No. $2,2002$.

${ }^{35}$ Wei, Zuobao, et al., "The Financial and Operating Performance of China's Newly Privatized Firms", Financial Management, V32, No. 2, 2003.
} 
Table 9. Performance Comparisons between SOEs and Privatized Firms

\begin{tabular}{|c|c|c|c|c|c|}
\hline Variables & $\mathrm{N}^{\mathrm{d}}$ & $\begin{array}{c}\text { Mean } \\
\text { Before } \\
\text { (Median) }\end{array}$ & $\begin{array}{c}\text { Mean } \\
\text { After } \\
\text { (Median) }\end{array}$ & $\begin{array}{l}\text { Mean } \\
\text { Change } \\
\text { (Median) }\end{array}$ & $\begin{array}{l}\text { Z-Statistic for Difference in Means } \\
\text { (After-Before) } \\
\text { (p-value) }\end{array}$ \\
\hline $\begin{array}{l}\text { Net Profit Level a } \\
\text { Privatized } \\
\text { SOE }\end{array}$ & $\begin{array}{l}39 \\
41\end{array}$ & $\begin{array}{l}0.79 \\
(0.59) \\
1.64 \\
(1.25) \\
\end{array}$ & $\begin{array}{l}1.59 \\
(1.14) \\
1.00 \\
(0.95) \\
\end{array}$ & $\begin{array}{l}0.80 \\
(0.55) \\
-0.64 \\
(-0.30) \\
\end{array}$ & $\begin{array}{l}3.44 * * * \\
(0.001) \\
-1.28 \\
(0.20) \\
\end{array}$ \\
\hline $\begin{array}{l}\text { Employment } \\
\text { Privatized } \\
\text { SOE }\end{array}$ & $\begin{array}{l}41 \\
41\end{array}$ & $\begin{array}{l}4660 \\
(1862) \\
2638 \\
(1594) \\
\end{array}$ & $\begin{array}{l}4784 \\
(1914) \\
2635 \\
(1426) \\
\end{array}$ & $\begin{array}{l}124 \\
(116) \\
-3 \\
(-168) \\
\end{array}$ & $\begin{array}{l}2.48 * * * \\
(0.01) \\
-1.114 \\
(0.26) \\
\end{array}$ \\
\hline $\begin{array}{l}\text { Sales Efficiency }{ }^{c} \\
\text { Privatized } \\
\text { SOE }\end{array}$ & $\begin{array}{l}41 \\
41\end{array}$ & $\begin{array}{l}0.71 \\
(0.68) \\
1.35 \\
(1.23) \\
\end{array}$ & $\begin{array}{l}0.84 \\
(0.73) \\
1.06 \\
(1.01)\end{array}$ & $\begin{array}{l}0.13 \\
(0.06) \\
-0.29 \\
(-0.22) \\
\end{array}$ & $\begin{array}{l}3.04 * * * \\
(0.00) \\
-2.86 * * * \\
(0.00) \\
\end{array}$ \\
\hline
\end{tabular}

Notes: The mean (median) values before and after year zero (1996, the year when the 41 firms were privatized) are calculated separately for each group. The before calculation uses a two-year average (199495) and after a three-year average (1997-99). The Wilcoxon signed rank test (z-statistic) is the significance of the mean change. The 'mean before' and 'mean after' values for net profit level and sales efficiency are normalized using the year zero $(1996=1.00)$ value.

${ }^{a}$ Net income after taxes; ${ }^{\mathbf{b}}$ Total No. of employees; ${ }^{\mathbf{c}}$ Sales/total employment; ${ }^{\mathrm{d}}$ No. of usable observations. *** Significant at the 0.01 level.

Source: Wei, Zuobao, et al. (2003).

However, though very promising, due to various constraints and limitations, the full potential of the private sector is far from being released. Instead, the private firms have to remain under a veil of informality, and have a limited ability to evolve beyond the first, informal stages of life and tend to become "stuck" in a framework of legal, financial, governance, and market structures because of their informal status.

Figure 4 Private Sector Development in China

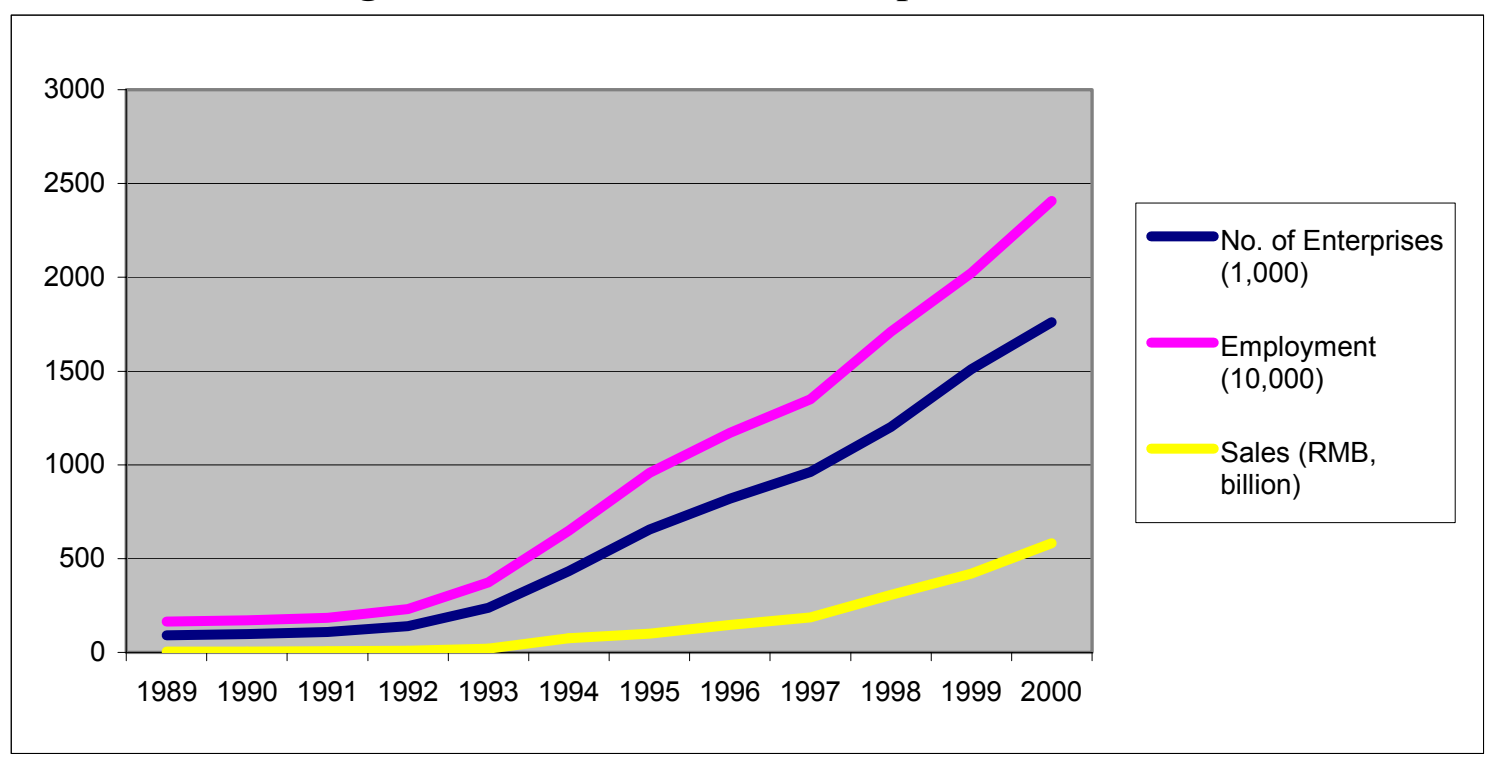

Source: International Finance Corporation Beijing office, and Helmut Schonleber, "China's Private Economy," presentation for the DIHT-ACFIC Partnership Project, 2001. 
In one sense, informality has been the private sector's great strength during a period of uncertainty and rapid change. It has allowed private enterprises to respond

flexibly to changing policies and regulations and to new market opportunities, while diversifying risk and avoiding excessive taxation, regulation, and competition. However, informality creates serious obstacles to the further growth and development of the sector, leaving large, mature companies stuck with structures more suited to small, young companies. It also makes companies opaque and unfocused, endows them with limited management capacity, and difficulty in attracting funding and skills they need to grow or survive. This is especially true for the self-employed businesses: since 1999, the number of self-employed began to drop, and by 2001, this number (48 million) has almost shrunk to the 1995 level (46 million). ${ }^{36}$ In order to survive in this somewhat uncertain political landscape of a transition economy and system, some private enterprises have to disguised themselves by 'wearing a red hat' (falsely declaring themselves as 'collectively owned'). ${ }^{37}$ This will inevitably hinder their operational efficiency.

In 1997, the private sector was recognized in a constitutional amendment. The amendment provides a basis of a better policy environment for private firms. The next important step would be to officially recognize private property. Although the 1999 Constitutional Amendment guaranteed protection to private property, such property was not placed on exactly the same footing as state property. Lack of security and fear of possible appropriation by the state are still disincentives for Chinese people to fully apply themselves, expand private businesses, and make long-term investments, thus hampering economic growth.

In order to encourage continuing private sector growth, the government should create a level playing field for all enterprises by intervening less, strengthening the legal framework for protecting the private property rights, providing incentives to lend to private businesses, and focusing on improved commercial legislation and more open markets. Financial institutions must develop to serve the private sector, by providing greater access to bank loans and credits. Meanwhile, the private enterprises also need to mature and improve their corporate governance, in order to derive the most benefit from improvements in the business environment. ${ }^{38}$

\section{III.2 Promoting Small and Medium Enterprises}

Small and medium enterprises (SMEs) tend to be the most dynamic part of a country's economy. Due to their entrepreneurship and flexibility, SMEs can be very competitive if matched with a sound business environment, skillful people and good governance. In China, since most SMEs, especially those in the urban areas, are in the tertiary sector, they have become an increasingly important source of job creation and reemployment for laid-off workers. According to Rong, small enterprises have a greater capacity for absorbing labor or generating new employment than large enterprises. Compared on a per

\footnotetext{
${ }^{36}$ China Statistical Yearbook, 1999, 2002, China Statistical Press, Beijing.

${ }^{37}$ Pannell, Clifton W., "China's Continuing Urban Transition", Environment and Planning, V34, No. 9, September 2002.

${ }^{38}$ IFC: China's Emerging Private Enterprises: Prospects for the New Century, 2000, Washington, DC, USA.
} 
unit of investment basis, the capacity for small enterprises to absorb labor could be as much as 14 times the capacity of large enterprises. ${ }^{39}$ However, at current stage, a large number of SMEs, notably the TVEs, are facing many constraints and challenges in a more and more competitive environment. The majority of TVEs have limited technological and human resources to become internationally competitive, ${ }^{40}$ and most SMEs in general have difficulties accessing financing, credits, technical assistance, market information, training and so on. In order to fully unleash the dynamism of SMEs for economic growth and employment generation, the government should undertake proactive strategies to help the development of SMEs in all sectors, from agriculture to services: ${ }^{41}$

- Drastically reducing the many regulatory hurdles for establishing and operating new private enterprises.

- Ensuring that small and medium-size enterprises have access to bank credit.

- Promoting informal lending schemes to small start-up businesses, such as group lending and special micro-venture schemes.

- Providing small and medium enterprises access to market and technical information.

- Setting up "small business incubator" to assist start-ups in finding appropriate technologies, skills, and venues/equipment, setting up managerial and accounting systems, and preparing relevant documents. ${ }^{42}$

- Developing formal and informal basic business and accounting skill training aimed at SMEs.

- Strengthening university and continuing education offerings relating to business and entrepreneurial skills.

- Drawing on extensive global experience on small and medium enterprise support programs, adapting the most relevant to the Chinese context (box 2).

\section{Box 2 Government Support for SMEs}

Small and medium-size enterprises account for significant economic activity in all high-income countries. In the EU they make up 93\% of firms, with nearly two-thirds of employment (more than 70 million

\footnotetext{
${ }^{39}$ See Mo Rong (2001), “Some Effects of China's Joining the WTO on Employment, and Certain Policy Proposals in Response to the Problem", The Chinese Economy, V34, No. 5, pp. 5-6. The paper was translated by M.E. Sharpe, Inc., from original Chinese text.

${ }^{40}$ Yao, Shujie, "China's Rural Economy in the First Decade of the $21^{\text {st }}$ Century: Problems and Growth Constraints", China Economic Review, V13, 2002, pp. 354-360.

${ }^{41}$ This section draws on World Bank, China \& Knowledge Economy: Seizing the $21^{\text {st }}$ Century, 2001, the World Bank, Washington, DC.

42 Jun, Tang, "Joining the WTO, the Employment Problem, and How to Deal With It", The Chinese

Economy, V34, No. 3, May-June 2001.
} 
people). In the United States, more than 50\% of private employees are employed by SMEs, and they account for $78 \%$ of employment in nonprimary industry in Japan. This is especially true of the service sector, where SMEs are particularly prevalent.

In order to promote these types of enterprises, governments of advanced countries enact policies and programs that promote entrepreneurial activity. Most OECD countries have specific agencies responsive for promoting small business. Agencies such as the Small Business Administration in the U.S., the Small and Medium Business Administration in South Korea, and the Small Business Service in the United Kingdom provide assistance and support for people trying to start a small business. However, there are often many regulatory hurdles that small business founders must contend with to gain access to the incentive programs and benefits provided by the government, which potentially discourages would-be entrepreneurs. Best practice in this area are "one-stop shops" for SME information and program benefits, such as One Stop Capital Shops in the U.S., and the UK's Direct Access Government online resource.

Lack of finance availability is a major impediment to small business growth. Governments often facilitate venture capital and other methods of financing in order to spur growth of small firms. In addition, many governments provide fiscal incentives, such as grants or tax breaks, to provide financial incentives for small enterprise growth. A particularly effective form of growth for SMEs is through exports. Therefore, many countries have also targeted SMEs with export credit programs and/or assisted them with accessing foreign markets.

Innovation is also an important part of small business development. Best-practice governments provide grants for $\mathrm{R} \& \mathrm{D}$ to small enterprise, as well as providing technological support through diffusion programs designed to promote the flow of expertise throughout the economy. In addition, ICT technologies are providing significant opportunities for cost cutting and to widen their market penetration through B2B and B2C ecommerce, providing opportunities for SMEs to serve very small market niches that might otherwise be impractical and unprofitable.

Table 10. Best Practice in SME Promotion

\begin{tabular}{|c|c|c|c|}
\hline Regulatory reform & $\begin{array}{c}\text { Funding and } \\
\text { promotion }\end{array}$ & Innovation and technology & Market access \\
\hline $\begin{array}{ll}\text { - } & \text { US - One Stop } \\
& \text { Capital Shops } \\
\text { - } & \text { UK (regional), Direct } \\
& \text { Access Government } \\
\text { - } & \text { Portugal - Centres for } \\
\text { - Company Formalities } \\
\text { - } & \text { South Korea - Small } \\
\text { and Medium Business } \\
\text { Association } \\
\text { - } \\
\text { Norway - Action Plan } \\
\text { for Small Enterprises } \\
\text { Turkey - Small and } \\
\text { Medium Industrial } \\
\text { Development } \\
\text { Organization } \\
\end{array}$ & $\begin{array}{l}\text { UK - Enterprise } \\
\text { Investment Scheme, } \\
\text { Venture Capital } \\
\text { Trusts } \\
\text { Netherlands - SME } \\
\text { Credit Guarantee } \\
\text { Scheme } \\
\text { US - Small Business } \\
\text { Investment } \\
\text { Companies, } \\
\text { NASDAQ } \\
\text { Denmark - } \\
\text { VaekstFonden Loan } \\
\text { Programme }\end{array}$ & $\begin{array}{ll}\text { - } & \text { US - Small Business } \\
\text { Innovation Research } \\
\text { programme } \\
\text { - South Korea - Enterprise } \\
\text { Information Incubator } \\
\text { Project } \\
\text { - Canada - Industrial } \\
\text { Research Assistance } \\
\text { Program } \\
\text { - Sweden - Foundation for } \\
\text { Technology Transfer } \\
\text { - } \\
\text { Ireland - Small Business } \\
\text { Operational Programme }\end{array}$ & $\begin{array}{ll}\text { - } & \text { Spain - } 100 \text { Policy for } \\
\text { - } & \text { TMEs } \\
\text { Turkey - Export } \\
\text { Credit Programme } \\
\text { - } \quad \text { US -Export Express } \\
\text { - } \text { Mexico - Export } \\
\text { Guidance System } \\
\text { - } \quad \text { Australia - Export } \\
\text { - Access Program } \\
\text { Netherlands - New } \\
\text { Businesses in Foreign } \\
\text { Markets }\end{array}$ \\
\hline
\end{tabular}

Source: OECD SME Outlook 2000. Paris.

\section{III.3 Expanding the Service Sector}

As an important measure of increasing employment and enhancing international competitiveness, the Chinese government should especially encourage the development 
of service industries. Due to past policy biases, the service sector in China is very underdeveloped for a country of its GDP per capita level (figure 5). In 2001, China's share of services in GDP (33.6) is even lower than that of Bangladesh (51.7), Kenya (62.9), Ethiopia (36.6), and Tanzania (39.4), not to mention the developed countries, and made almost no progress from the 1991 level of 33.4 percent. Although China has an impressive FDI (foreign direct investment) stock, most of it $(66.6 \%)$ is concentrated in manufacturing and related industries, with only $31.6 \%$ in services in 2000. Furthermore, the bulk of this investment (23.6\% of total FDI) goes to the real estate business, leaving only $8 \%$ in other service industries. ${ }^{43}$ This unbalanced structure is mainly due to the policy constraints imposed on foreign participation in services.

Figure 5 Underdeveloped Service Sector in China

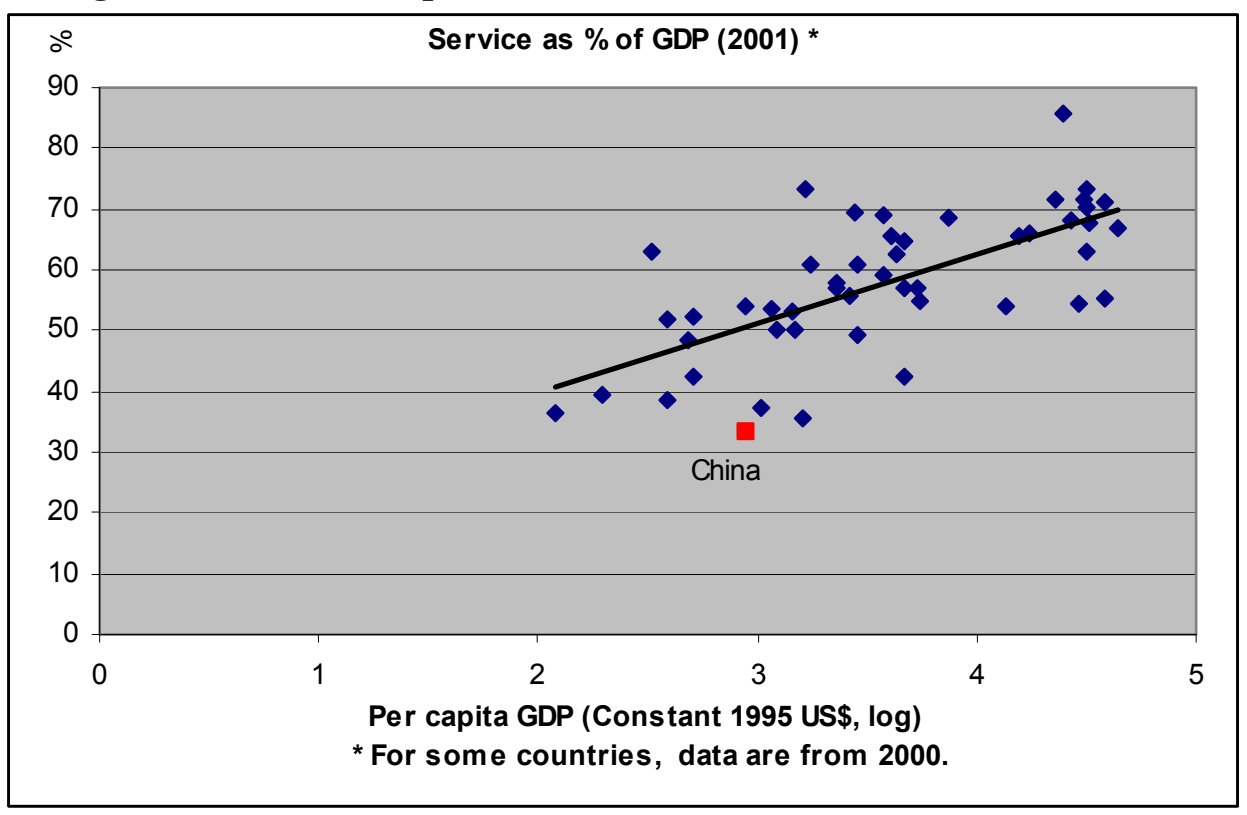

Source: World Bank SIMA database.

In the short and medium terms, the underdeveloped service sector will be the major source for economic development and job creation. It is generally believed among Chinese scholars that a 1\% increase in GNP would create either 800,000 jobs in secondary industry or 1.3 million new jobs in the tertiary sector. ${ }^{44}$ The potential for growth is huge in such industries as financial and insurance services, business management, technical consulting, telecom, law, distribution, sales, marketing, advertising, public relations, accounting, computer programming, E-commerce, logistics, travel, and tourism. The rapidly developing urban informal service sector, such as restaurants, retailing, construction, repair, housing and delivery services, has become the major source of absorbing the rural-urban migrants. Within this sector, the self-employed

\footnotetext{
${ }^{43}$ China FDI Net: http://www.chinafdi.org.cn/

${ }^{44}$ Lee, Hong Yung, "Xiagang, The Chinese Style of Laying Off Workers", Asian Survey, V40, No. 6, November/December 2000.
} 
group has generally acted as a long-term employment opportunity for migrants. ${ }^{45}$ From 1993-2001, while employment in the traditional urban formal sector has been shrinking (from $81.4 \%$ to $36.1 \%$ ), the urban informal sector (where services account for the major part) has been adding workers rapidly (from $6.3 \%$ to $15.3 \%$, though it had a slight decline in 2000 mainly due to a reduction in self-employed, see table 11). In addition, service industries in small towns would be an important resort for redundant rural labor, where public services, transportation, warehousing and trading of agricultural products, and information and technical services will have great room for expansion. Based on a

Table 11. Changes in the Urban Employment Structure (1990-2001, millions)

\begin{tabular}{|c|c|c|c|c|c|}
\hline \multirow[t]{2}{*}{ Year } & \multirow{2}{*}{$\begin{array}{c}\text { Total } \\
\text { Urban } \\
\text { Employed }\end{array}$} & \multicolumn{2}{|c|}{ Traditional Formal Sector } & \multicolumn{2}{|c|}{ Informal Sector } \\
\hline & & $\begin{array}{l}\text { Total number of } \\
\text { staff and workers }\end{array}$ & $\begin{array}{c}\% \text { in total urban } \\
\text { employed }\end{array}$ & $\begin{array}{c}\text { Total number of } \\
\text { employment }\end{array}$ & $\begin{array}{c}\% \text { in total urban } \\
\text { employed }\end{array}$ \\
\hline 1990 & 166.16 & 138.95 & 83.6 & 6.71 & 4.0 \\
\hline 1991 & 169.77 & 142.92 & 84.2 & 7.60 & 4.5 \\
\hline 1992 & 172.41 & 145.10 & 84.2 & 8.38 & 4.9 \\
\hline 1993 & 175.89 & 143.13 & 81.4 & 11.16 & 6.3 \\
\hline 1994 & 184.13 & 141.01 & 76.6 & 15.57 & 8.5 \\
\hline 1995 & 190.93 & 140.31 & 73.5 & 20.45 & 10.7 \\
\hline 1996 & 198.15 & 139.03 & 70.2 & 23.29 & 11.8 \\
\hline 1997 & 202.07 & 135.83 & 67.2 & 26.69 & 13.2 \\
\hline 1998 & 206.78 & 107.09 & 51.8 & 32.32 & 15.6 \\
\hline 1999 & 210.14 & 99.88 & 47.5 & 34.67 & 16.5 \\
\hline 2000 & 231.51 & 93.24 & 40.3 & 34.04 & 14.7 \\
\hline 2001 & 239.40 & 86.50 & 36.1 & 36.58 & 15.3 \\
\hline
\end{tabular}

Notes: 1. The "traditional formal sector" refers to the urban state-owned and collective units, and the "informal sector" refers to the domestic informal private and self-employed units (mostly enterprises). In the urban employment, except these two categories, there are also the "emerging formal sector", which includes units (mostly enterprises) with joint, share-holding, or limited liability ownerships (which can be broadly defined as 'formal private'. Refer to table 8), as well as foreign and Hong Kong, Macao, and Taiwan ownerships and their affiliates. Also, for the "traditional formal sector", here we only include the "staff and workers", which refer to the full-time employees but exclude the re-hired retirees.

2. In the Chinese statistics, the "total urban employed" also includes the laid-off or Xiagang workers from state-owned and collectives. These workers have been laid off while still nominally holding an employment relationship (or contract) with their enterprises or units. However, many of them do not receive any living expenses from their units or have any other source of income, and they should be categorized as "unemployed". This is one of the reasons that, in the Chinese statistic books, there is a discrepancy between the total employed and the total number of employees in all formal and informal sectors adding together.

Source: China Labor Statistical Yearbook 2002, China Statistics Yearbook, various years, and Hu, Angang (2001).

preliminary estimation, by 2005 , about 33 percent of China's labor force will be working in the service sector, which is expected to recruit about another 30 million new employees in the coming years.

Service industries are knowledge and labor-intensive, and therefore are particularly necessary for the transition to a knowledge based society. Their businesses are also crosscutting all other sectors, thus, productivity gains made in service sector industries not only benefit the service industries themselves, but benefits also trickle down through

\footnotetext{
${ }^{45}$ See Meng, Xin's study (2001) based on a survey of 1504 rural-urban migrants in Jinan city, Shandong Province in 1995. "The Informal Sector and Rural-Urban Migration - A Chinese Case Study", Asian Economic Journal, V15, No.1, 2001.

46 “Call for More Jobs in China's Service Sector”, Asia Times, April 27, 2002: http://www.atimes.com.
} 
other sectors, including manufacturing and agriculture, leading to huge productivity and efficiency gains in all segments of the economy.

Currently most of the service industries in China are still dominated by state monopolies or oligopolies, such as banking, distribution, transportation, telecommunications, media, utilities, logistics, health care, and even tourism. In order to fully unleash the potential of the service sector, the government needs to deregulate the sector, introduce more competition, and gradually open it to foreign investors, and particularly encourage the private sector to participate in the service industries.

\section{III.4 Reforming the State-owned Enterprises}

China's network of nearly 200,000 state-controlled companies once formed the backbone of the nation's economy, but now hangs like an albatross around Beijing's neck. The SOEs' contribution to China's gross domestic product fell from nearly $100 \%$ in the early 1980s to about $30 \%$ in 2000 as the more efficient private and semi-private sector outpaced the state sector. However, still employing over 53 million people ${ }^{47}$ and accounting for about $60 \%$ of government revenues in 2001, SOEs continue to play an important role in the Chinese economy, and their restructuring or transformation can be cited as the most challenging industrial policy problem faced by any government in the world. In order to maintain them, the government propped up the loss-making firms with loans from state-controlled banks and saddled itself with hundreds of billions of dollars of non-performing loans.

In the past five years, the government also adopted the strategy of selling or privatizing smaller state-owned enterprises and laying off workers to improve efficiency and productivity. These policies were marginally successful but contributed to a sharp rise of unemployment. In May 2003, the government launched a new plan by creating the central State Assets Supervision and Administration Commission (SASAC). The new commission's priorities are to ensure better management and curtail the loss of assets by separating the ownership and management aspects of the state-owned firms. The commission's goal is to eventually reconstruct 30 to 50 state enterprises and build them into internationally competitive firms. Meanwhile, the government allows foreign firms to merge or acquire SOEs, not only small and medium ones, but those ranked as top 500 in China. ${ }^{48}$

Although the role of government in SOEs' management and operation has been reduced under the Modern Enterprise System and Group Company System reforms ${ }^{49}$ since 1993, central ministries and local governments still retain influence or authority, especially on major management and personnel decisions. Downsizing SOE management has proved to be very difficult, since the party itself still has ultimate power over SOE managers' appointments above a certain level, as well as great influence over many managers who

\footnotetext{
${ }^{47}$ National Bureau of Statistics of China, China Statistical Abstract 2003, China Statistics Press, 2003 , p51. This figure only refers to those employed in the state-owned and state-controlled enterprises.

${ }^{48}$ China Development Gateway: http://www.chinagate.com.cn.

${ }^{49}$ Which were intended to restructure enterprises based on the principle of corporatization, and separate state's exercise of ownership rights from the enterprise's exercise of legal person property rights.
} 
are party members. ${ }^{50}$ International experiences show that the state does not necessarily have to get out of the production entirely, but that it should get out of sectors that are not strategic, or those in which it does not have a comparative advantage.

To make the SOEs more efficient and productive, the government should take the following measures:

- Expediting the reform of SOE corporate governance structures to curtail government interference and reduce the dominance of insiders. As long as the party or government appoints the top managers, the SOEs will only respond to their bosses within the party or government instead of reacting to the needs of the market. SOEs should be given more autonomy with elected managers and independent boards of directors, which should be the highest level of decision making, while government representatives, whatever their level, should be separated from business decisions. For those privatized former SOEs, government should fully withdraw its direct interference and allow them to operate in a market-based mechanism.

- Adopting a narrow definition of the SOE core to include only those industries such as defense, aerospace, aviation, electricity, gas and so on, where continued government involvement is essential on economic grounds.

- Unbundling social service functions. SOEs are burdened by obligations to provide housing, pension, medical treatment, basic education and other social services. The unbundling will require the rapid establishment of a social security system and other safety nets.

- Resolving the asset ownership. The state assets should be well protected by law and not be freely used, sold, or transformed by enterprise management. The establishment of SASAC seems a great step towards this direction.

- Accelerating the financial reforms, in particular the development of bond markets; and of smaller banks and other financial institutions as alternatives to the four large state commercial banks, and improving the monitoring and supervision of bank loans. Meanwhile, the creditors' role in corporate control should be strengthened. Allowing greater room for commercial bank involvement in investment banking activities, such as providing securities advice and custodial services that can lead to proxy voting by banks, will enhance banks' role in corporate governance. ${ }^{5}$

- Facilitating the spin-off or creation of small private enterprises from bankrupt and other state enterprises through policy incentives. Some good examples can be identified in Shanghai and Beijing, where the municipal governments help surplus workers from SOEs set up new small businesses on their own by easing registration procedures and offering tax holidays. ${ }^{52}$

\footnotetext{
${ }^{50}$ Sheehan, Jackie, J. Morris and J. Hassard, "Redundancies in Chinese State Enterprises: A Research Report", Industrial Relations, V39, No. 3, July 2000.

${ }^{51}$ Tenev, Stoyan and C. Zhang, "Corporate Governance and Enterprise Reform in China", the World Bank and the International Finance Corporation, Washington, D.C., 2002

${ }^{52}$ Sheehan, Jackie, J. Morris and J. Hassard, "Redundancies in Chinese State Enterprises: A Research Report”, Industrial Relations, V39, No. 3, July 2000.
} 


\section{III.5 Strengthening the Social Security System}

Considering the current and foreseeable future large unemployment and joblessness in China, to strengthen or establish a nation-wide social security system and appropriate social safety nets, or so called "social infrastructure", ${ }^{53}$ is essential for its long-term development and stability. Such a system would relieve SOEs from excess financial burdens and make them more productive, facilitate labor mobility, and help prevent unemployed population from slipping into poverty.

Since 1998, the Chinese government has adopted a "two guarantees" system. The first is a guarantee of the basic living of the laid-off workers from SOEs. The second guarantee is to ensure basic living for all retirees and that they receive basic pensions in full and on time. To ensure the implementation of the "two guarantees," the Chinese government implemented three corresponding policies: laid-offs from SOEs can receive a basic living allowance from the reemployment service centers ${ }^{54}$ for a maximum of three years; if they still haven't found a job by then, they can receive unemployment insurance ${ }^{55}$ payments for a maximum of two years; and at the end of the two-year period, if they still haven't been reemployed, they can apply for the urban minimum living allowance. These are the so-called "three social security lines" in China. By 2001, the majority of people laid off by SOEs were receiving a basic living allowance, and retired personnel were receiving their pensions in full and on time. Meanwhile, the government has tried to consolidate these different systems. Starting from January 2001, no more new reemployment centers would be established for SOEs in principle, and the new laid-offs would directly enjoy unemployment insurance, which is also being gradually integrated with the minimum living guarantee system. ${ }^{56}$

The major problems of the current social security system are the limited funding (insurance funding per unemployed worker is about 210 yuan in early 2003), small coverage (less than $10 \%$ of the total population with the rural areas barely covered), lack of detailed macro policy analyses and coordination among relevant ministries, as well as deficiencies in implementation. Arrears of payments are often serious, since enterprises in difficulty cannot furnish their share for the basic living allowance or unemployment insurance, while many government civil affairs agencies are not properly funding or implementing the minimum living allowance policy. ${ }^{57}$ In some cases, even people still

\footnotetext{
${ }^{53}$ Huang, Fan-Zhang, "The Current Economic Situation and Trends in China with a Discussion on Employment-related Issues in the Process of Industrialization", from Restructuring Asian Economics for the New Millennium, Volume 9-A, Amsterdam; New York and London: Elsevier Science, JAI, 2001. ${ }^{54}$ Reemployment service centers were established mainly from 1998 to deal with SOE laid-offs. The centers give laid-off workers allowances for basic living expenses and pay social insurance premiums for them, with the required funds coming from the government budget, enterprises and other sources (mainly unemployment insurance funds). They also provide job guidance and organize reemployment training programs to help laid-off workers find new jobs.

${ }^{55}$ Paid by contributions of enterprises, institutions and employees; interest of the unemployment insurance fund; fiscal subsidy; and others. Urban enterprises and institutions are required to contribute $2 \%$ of their total wage amounts; and employees $1 \%$ of their personal wages.

${ }^{56}$ Zhang, Juwei, "Urban Xiagang, Unemployment and Policy Support", a background study for the World Bank, 2003.

${ }^{57}$ Solinger, Dorothy J., "Labor Market Reform and the Plight of the Laid-off Proletariat," The China Quarterly, No. 170, June 2002.
} 
working may not get paid, and in other cases, it is difficult to identify those with other source of income or new employment: some laid-off workers with income continue to receive compensation, while many without an income source do not receive payments. ${ }^{58}$

All these issues have to be addressed through a concerted, well coordinated effort across the government agencies (such as ministries of labor, personnel, finance, civil affairs, and State Development and Reform Commission), public/private sectors, and urban/rural areas. An urgent need is to increase the funding for the minimum living guarantee system. Although the fiscal budget for minimum living guarantee system reached nearly 11.5 billion yuan in 2002, it only accounted for tiny $0.1 \%$ of its total GDP or less than $0.5 \%$ of the total government fiscal expenditure (table 12). This is very low compared with developed countries. Figures of developed countries in mid 1990s show that, on average, they spent about 1-2\% of GDP for their social relief system, about 10 times that of China. Considering the huge needs and massive unemployment in China, the governments at all levels have to substantially increase their funding for the social security system.

Table 12. Scale and Magnitude of the Urban Minimum Living Guarantee Fund (19962002)

\begin{tabular}{|c|c|c|c|c|c|c|}
\hline \multirow[t]{2}{*}{ Year } & \multirow{2}{*}{$\begin{array}{l}\text { People } \\
\text { covered } \\
\text { (million) }\end{array}$} & \multicolumn{3}{|c|}{$\begin{array}{l}\text { Minimum Living Guarantee Fund (100 } \\
\text { million yuan) }\end{array}$} & \multirow[t]{2}{*}{$\begin{array}{l}\text { Share of } \\
\text { GDP }(\%)\end{array}$} & \multirow{2}{*}{$\begin{array}{c}\text { Share of total } \\
\text { fiscal } \\
\text { expenditure }(\%)\end{array}$} \\
\hline & & Total & $\begin{array}{c}\text { Central } \\
\text { government }\end{array}$ & $\begin{array}{c}\text { Local } \\
\text { government }\end{array}$ & & \\
\hline 1996 & 0.85 & 3.0 & 0.0 & 3.0 & 0.004 & 0.04 \\
\hline 1997 & 0.88 & 11.5 & 0.0 & 11.5 & 0.004 & 0.03 \\
\hline 1998 & 1.84 & 12.0 & 0.0 & 12.0 & 0.015 & 0.11 \\
\hline 1999 & 2.81 & 19.7 & 4.0 & 15.7 & 0.024 & 0.15 \\
\hline 2000 & 3.82 & 29.6 & 8.0 & 21.6 & 0.034 & 0.19 \\
\hline 2001 & 11.32 & 54.2 & 23.0 & 31.2 & 0.055 & 0.28 \\
\hline 2002 & 19.30 & 114.7 & 46.0 & 68.7 & 0.112 & 0.52 \\
\hline
\end{tabular}

Source: China National Bureau of Statistics, China Statistic Yearbook, 2002, 2003. Hong Dayong (2003), "Latest Development of Urban Minimum Living Guarantee System", China Social Development Research Report 2002, Publishing House of People's University, p124.

Meanwhile, while the fund size is increased, the scope of the minimum living guarantee fund should gradually be expanded to cover the long-term rural migrant workers in the urban areas, who have become part of urban dwellers, and also the most vulnerable group in the cities. Once they are unemployed, their risk of falling into poverty is higher than the local urban dwellers. Table 13 shows the current composition of the minimum guarantee recipients, with no rural migrants covered at all.

Table 13. Composition of the Urban Minimum Living Guarantee Recipients (2001-2002)

\begin{tabular}{lcccc}
\hline & \multicolumn{2}{c}{ June 2001 } & \multicolumn{2}{c}{ June 2002 } \\
\hline \multicolumn{1}{c}{ Category } & Number $(10,000)$ & Share $(\%)$ & Number $(10,000)$ & Share (\%) \\
\hline On-post workers $^{\text {a }}$ & 58 & 12.66 & 191 & 9.89 \\
Xiagang workers $^{\text {b }}$ & 110 & 24.02 & 255 & 13.21 \\
Off-post workers $^{{ }^{c}}$ & 0 & 0.00 & 442 & 22.89 \\
Retired workers & 26 & 5.68 & 93 & 4.82 \\
\hline
\end{tabular}

\footnotetext{
${ }^{58}$ Cook, Sarah and S. Jolly, Unemployment, Poverty and Gender in Urban China: Perceptions and Experiences of Laid Off Workers in Three Chinese Cities, Institute of Development Studies, Sussex, England, August 2000.
} 


\begin{tabular}{lcccc}
\hline Unemployed workers & & & & \\
Dependents \& others & 76 & 16.59 & 299.3 & 15.50 \\
Socially Disadvantaged People & 135 & 29.48 & 554 & 28.69 \\
Total & 53 & 11.57 & 96.5 & 5.00 \\
\hline
\end{tabular}

Notes: ${ }^{a}$ Those who have jobs but whose salaries are below the urban minimum living guarantee line.

${ }^{\mathrm{b}}$ The laid-off workers from state-owned or collective units, who still have nominal employment relationships with their units and normally receive certain small amounts of allowances.

${ }^{c}$ There are different situations in this category: some have terminated their employment relationships with their original units either voluntarily or involuntarily, and some still have relationships but not in duty due to unpaid leave (sometimes involuntarily), illness, etc., but they are not officially registered as unemployed. ${ }^{d}$ Those officially registered as unemployed at labor administration.

Source: Hong Dayong (2003), "Latest Development of Urban Minimum Living Guarantee System", China Social Development Research Report 2002, Publishing House of People's University.

On the other hand, it is a very challenging issue how to include the increasing number of rural migrants into the guarantee system. One possible way is to first include those who have lived and worked long enough in urban areas (for example, minimum one year). Another possibility is to consider establishing a nationwide minimum living guarantee system, and connecting the rural minimum guarantee system with the urban one. Furthermore, the enforcement of unemployment policies has to be strengthened by various levels of governments, employers, and other related parties.

Also, in order to better utilize the limited resources, the unemployment-related relief system should not be only a welfare system that just hands out money, but an incentivebased unemployment system, which is linked to achievements such as re-education, retraining or re-skilling.

In addition to the basic living guarantee and unemployment insurance systems, other social safety nets need to be established as well, such as low-income housing, health systems, pension and disability funds, and other transferable benefit packages.

\section{III.6 Improving the Labor Market Flexibility}

The Chinese Government has acknowledged the importance of a well functioning labor market to support economic restructuring and address the problem of deepening inequalities in China, and has taken important steps to improve the labor market, however, it is far from being complete and faces many challenges. Among the existing labor market pressures, the 150 million surplus rural farm labors and 15 million unemployed urban labors unevenly distributed across China are the most severe ones. In addition, the large "floating population" without residency permits in urban areas may range from 90 to 150 million people, or $13 \%$ to $21 \%$ of the labor force. Without proper "hukou" (household registration), these people are forced to find low-paid unsavory employment in the black market. Labor mobility, especially rural-urban migration, seems crucial for alleviating these pressures and the associated social stress and inequalities, ${ }^{59}$ especially when farmers have become increasingly reliant on off-farm employment and

\footnotetext{
${ }^{59}$ Dahlman, C. and J. Aubert, China \& Knowledge Economy: Seizing the $21^{\text {st }}$ Century, 2001, the World Bank, Washington, DC.
} 
income opportunities for raising income. ${ }^{60}$ According to a study by Knight and Song, non-farm activities in China are more rewarding than farm activities, both on average and at the margin. ${ }^{61}$ Dealing with all these challenges and a huge labor force with a size of that in China requires a much more flexible labor market.

Currently, the labor market in China is highly fragmented because of tough restrictions on migration, as well as other constraints on mobility such as geographically segmented and outmoded systems for social insurance and public services provision. ${ }^{62}$ The labor market segmentation exists not only between urban-rural, but also within the urban and rural labor markets, and between the migrant and non-migrant. The biggest constraint on labor mobility is the household registration or hukou system. Under such a system, legal residence in a village, town or city is initially defined at birth and determines entitlements to local jobs, housing, schooling, healthcare and social security, and, in rural areas, to farming land as well. Unapproved migration can be extremely costly in terms of lost entitlements, and even approved movement can involve substantial losses, for example loss of claims on agricultural land without compensation. ${ }^{63}$ This makes it very difficult to migrate between the rural and urban, between rural areas, between cities and between provinces (particularly workers with low qualifications), thus exacerbating the unemployment problem. Furthermore, the restrictions on labor mobility widen the income disparity between the coastal areas and the rest of China, and inflate the numbers entering illegal professions, such as prostitution, drug dealing, and smuggling. Instead, allowing labor moving out of agriculture and informal labor moving into formal activities, could result in substantially higher average marginal productivity, which is the source of the additional welfare gain. ${ }^{64}$

Another important barrier to off-farm labor mobility is the absence of well-defined property rights for agricultural land. This leads to the retention of additional labor in the farm sector, because farm households have to consider the returns to land in their decision to work on- or off-arm, since leaving the farm means losing the land.

In addition, there is more room for flexibility in employment policies. The introduction of contract employment in industry from 1986, which was intended to apply to all new entrants to the workforce, has contributed to firms' greater flexibility and efficiency, however, it's scope is still limited. In the state sector, poorly performing managers are

\footnotetext{
${ }^{60}$ Kung, James L. S. and Y. Lee, "So What If There is Income Inequality? The Distributive Consequence of Nonfarm Employment in Rural China", Economic Development and Cultural Exchange, V50, No.1, October 2001.

${ }^{61}$ Knight, J. and L. Song, "Chinese Peasant Choices: Migration, Rural Industry or Farming", Oxford Development Studies, V31, No.2, June 2003. Similar patterns have been obtained in other studies of rural household income functions. For instance, Zhao (1996) estimated the marginal income for an additional farm worker, local non-farm worker and migrant worker to be 5, 19 and 55\%, respectively, in Sichuan. See Zhao, Y., "Labor Migration and Education in Rural Sichuan Province: A Special Pattern", International Conference on the Flow of Rural Labor in China, Beijing, 25-27, June 1996.

${ }^{62}$ Fox, L. and Y. Zhao, "China's Labor Market Reform: Performance and Prospects," a background study for the World Bank, 2002.

${ }^{63}$ OECD: China in the World Economy: the Domestic Policy Challenges, Paris, 2002.

${ }^{64}$ See a simulation study by Gilbert, John and T. Wahl (2003), using applied general equilibrium techniques, in "Labor Market Distortions and China's WTO Accession Package: An Applied General Equilibrium Assessment", Journal of Comparative Economics, No. 31, pp. 774-794.
} 
still generally only moved sideways (within or between enterprises) instead of being really bound by contract terms. ${ }^{65}$ An empirical study of thirty food enterprises in China's Guangdong Province also found that flexibility in the use of temporary or contract workers (those who do not have job tenure in their enterprises) could produce a positive effect on enterprise productivity. This finding supports the need for more flexibility in employment policies. ${ }^{66}$

In order to address all these issues, carefully gauged but effective measures need to be taken to enhance the labor flexibility, including further relaxing the hukou system. At initial stage, the hukou system can be partially dismantled, i.e., keeping some of its benefits attached to geography (such as education or retraining), but allowing others, including the ability to be employed and health care, to move with the population. Better labor mobility across enterprises, sectors and geographical areas, would facilitate further restructuring and mitigate its economic and social cost, including frictional and structural unemployment, underemployment, and income inequality. For the vast rural surplus labors and "floating population", migration, under a flexible and healthy labor market framework, provides a mechanism for ensuring them not to be adversely affected by the trade reforms after the WTO entry, but actually sharing its benefits. The reform of the hukou system and land use rights, more flexible employment policies, establishing of social safety net and development of affordable housing market, would effectively facilitate the labor mobility and enterprise efficiency.

Modeling results by Zhai, et al. (using the computable general equilibrium model), show that the net benefit from WTO membership will be maximized if China adopts a policy gradually to relax its rural-urban migration control in conjunction with a labor market reform, including the relaxation of the hukou system and land reform. Doing so not only prevents a dramatic worsening of the urban unemployment problem, but also permits enough labor market flexibility to create more employment opportunities for rural unskilled migrant labors. Furthermore, the combined impact of WTO accession and labor market reforms reduces rural-urban income inequality quite significantly (the urban/rural income gap would reduce by $46.5 \%$, and the national Gini coefficient would fall about $3.5 \%$ by 2007). ${ }^{67}$ Ianchovichina and Martin also estimated that the removal of the hukou system would raise farm wages and allow 28 million people to migrate to non-farm jobs in search of a better life. A combination of removal of the hukou system and an increase in skill levels is the most favorable scenario for unskilled farm labor leading to the largest increase in real farm wages (19.4\% from 2001 to 2007$).{ }^{68}$

In addition, the various existing employment service centers should be strengthened so that they can provide job search assistance, retraining, and certain guidance and

\footnotetext{
${ }^{65}$ Sheehan, Jackie, J. Morris and J. Hassard, "Redundancies in Chinese State Enterprises: A Research Report”, Industrial Relations, V39, No. 3, July 2000.

${ }^{66}$ Mok, Vincent Wai-kwong, "Industrial Productivity in China: the Case of the Food Industry in Guangdong Province”, Journal of Economic Studies, V29, No.6, 2002.

${ }^{67}$ Zhai, Fan, et al., "WTO Accession, Rural Labor Migration and Urban Unemployment in China", Urban Studies, V39, No. 12, 2002; Zhai, Fan, T. Hertel and Z. Wang, "Labor Market Distortions, Rural-Urban Inequality and the Opening of China's Economy”, GTAP working paper, No. 27, May 2003.

${ }^{68}$ Ianchovichina, Elena and W. Martin, "Economic Impacts of China's Accession to the World Trade

Organization”, World Bank policy research working paper, the World Bank, May 2003.
} 
forecasting of future employment needs. The internet can be used to establish on-line job databases where people can post resumes and apply for jobs and the headhunters can identify appropriate candidates without geographical limitations.

Beyond these actions, the government also needs a labor-using development policy, which could include: investing in public infrastructure, such as feeder roads, water supplies, and other basic social infrastructure, especially in the Western provinces; and developing small cities and towns creating construction that will absorb access labor. However, it is also important to consider the feasibilities and the sources of livelihood for those cities and towns before they were built.

\section{III.7 Establishing Mass Retraining Programs}

China's drastic economic restructuring and SOEs reforms make it extremely important to carry out large nationwide labor retraining programs for the massive number of displaced and laid-off workers. From 1998 to 2000, 21.37 million people had been laid off from China's SOEs, amounting to over 37 percent of the total work force of 57 million in this sector in 2000. ${ }^{69}$ Most of the "Xia-gang" (laid-offs) took place in China's old industrial centers and underdeveloped regions such as northeast provinces and middle west provinces, and concentrated in mining, textile, machinery equipment and military equipment manufacturing sectors. The majority of the laid-off workers have a very limited education background (table 14).

Table 14. Urban Unemployment in China by Education Background (2001, unit: 10,000 persons)

\begin{tabular}{|c|c|c|c|}
\hline Total & College and above & Upper secondary & $\begin{array}{c}\text { Lower secondary and } \\
\text { below }\end{array}$ \\
\hline 681.0 & 41.5 & 247.9 & 391.6 \\
\hline $100 \%$ & $6.1 \%$ & $36.4 \%$ & $57.5 \%$ \\
\hline
\end{tabular}

Source: China Labor Statistical Yearbook 2002, China Statistics Press, 2002, and author's calculation.

In response to the massive unemployment problem, Chinese government has launched several retraining programs to help laid-off workers re-skill themselves and enhance their re-employability. A pilot "Reemployment Project" was initiated by Ministry of Labor and Social Security (MOLSS) in 30 municipalities in 1994 and then expanded to 200 cities in 1995-96. Following the success of this pilot project, the MOLSS again in 1998 launch another reemployment project "Ten Million in Three Years" which means to provide reemployment training and job counseling services for 10 million laid-off workers in the duration of three years. In 2001, a second round of "Ten Million in Three Years" program was launched by MOLSS for the period of 2001-03. In addition, the government also launched other programs, such as "Warmth Project", organized by the National Association of Vocational Education of China (NAVEC).

Table 15. Training Results from 10 Sample Provinces (1998)

\footnotetext{
${ }^{69}$ Chinese Ministry of Labor and Social Security: China Labor Market. http://www.lm.gov.cn/gb/content/2002-05/20/content_1383.htm. China Statistical Yearbook 2001.
} 


\begin{tabular}{|l|l|l|l|}
\hline Province & $\begin{array}{l}\text { Laid-off workers } \\
(10,000 \text { persons })\end{array}$ & $\begin{array}{l}\text { People trained (10,000 } \\
\text { persons) }\end{array}$ & Reemployment rate (\%) \\
\hline Heilongjiang & 62 & 46 & $65 \%$ \\
\hline Liaoning & 35 & 19.7 & $40 \%$ \\
\hline Chongqing & 11 & 4 & $71 \%$ \\
\hline Guangdong & 45 & 24 & $70 \%$ \\
\hline Hubei & 32 & 11 & $58 \%$ \\
\hline Hunan & 44.8 & 8 & $72 \%$ \\
\hline Fujian & 3 & 1.3 & $46 \%$ \\
\hline Henan & 23.7 & 13.4 & $46 \%$ \\
\hline Ningxia & 3.5 & 2.6 & $30 \%$ \\
\hline Xinjiang & 4 & 1.5 & $27 \%$ \\
\hline
\end{tabular}

Source: China Employment Training Center, 1998.

The results of these training programs were variant from province to province (table 15), for example, in Hunan, $72 \%$ of people were reemployed after training while in Xinjiang, only $27 \%$ were reemployed after training. An evaluation study by the research group at the World Bank on the retraining programs in Shenyang and Wuhan also showed mixed results. ${ }^{70}$ In general, retraining programs had a positive impact on the reemployment prospects of trainees in Wuhan, while in Shenyang they seemed to be ineffective. In both cities, training didn't put any impact on trainees' earnings. Training results were also different for workers of different gender, age and education backgrounds. The study also showed that the design of training programs had an impact: the longer-duration programs usually yielded better results. Meanwhile, more positive results can be seen from those programs where trainees had to pay at least part of the training costs. In addition, a survey conducted among the unemployed in August 2001 by the Ministry of Labor and Social Security in 10 large cities showed that 70 percent of the people surveyed had participated in re-employment training, but only half thought that the training was useful in helping them find jobs. ${ }^{71}$

In order to maximize the effects, retraining programs need to be tailored to the job opportunities and to the ages and backgrounds of the workers to be retrained. One good example can be drawn from Shanghai's case. The economic restructuring and SOE reform led to the shedding of about 500,000 textile workers in Shanghai since the end of 1980s. Most of the workers made redundant were women in their 40s and 50s with little education and few marketable skills. The Textile Re-employment Service Center, sponsored by the municipal government, set up several dozen training bases focusing on computer techniques, accounting, cooking, sewing and other skills. After massive retraining, an estimated $70 \%$ of the redundant workers were reemployed, while the remaining 30\% chose early retirement or self-employment. Only one year after the Textile Re-employment Center was opened, Shanghai's textile sector had restructured 164 loss-making enterprises by either shutting them down, suspending production or shifting to manufacturing other goods. ${ }^{72}$ This experience definitely has applications to the rest of China.

${ }^{70}$ The World Bank: "Has Training Helped Employ the Xiagang in China? A Tale from Two Cities", East Asia and Pacific Region, the World Bank, 2002.

71 "Urban Jobless Face Difficulty in Re-employment", China Internet Information Center, China.org.cn, September, 2001.

${ }^{72}$ Fruman, C., "Life-long Learning in China: A Case Study of Shanghai," the World Bank, 2003. 
In addition to tackling the current urgent reemployment training needs mostly from SOEs, China should also find ways to train the increasing number of rural emigrants (most of whom only have lower secondary education level, table 16), and to deal with the huge future demand for continuous education or on-the-job training as projected in table 17. The government should also provide training and various support services for SMEs and new business start-ups. The training could focus on basic or core business skills, such as accounting, financing, marketing, business plan development, business registration, and taxation.

Table 16. The Educational Levels of the Rural Emigrants (\%, 1997-2000)

\begin{tabular}{|l|l|l|l|l|}
\hline & 1997 & 1998 & 1999 & 2000 \\
\hline Illiterate or half-illiterate & 1.9 & 1.6 & 1.5 & 1.2 \\
\hline Primary & 21.3 & 19.9 & 18.6 & 18.1 \\
\hline Junior Secondary & 58.5 & 58.7 & 59.7 & 61.2 \\
\hline Senior Secondary & 13.8 & 14.3 & 14.2 & 13.4 \\
\hline Secondary Professional Schools & 3.5 & 4.3 & 4.6 & 4.7 \\
\hline College or above & 1.0 & 1.3 & 1.3 & 1.4 \\
\hline
\end{tabular}

Source: MOE: China Education \& Human Resource Report - Stride from a Country of Tremendous

Population to a Country of Profound Human Resources, Part Four, Higher Education Press, Beijing, 2003.

Table 17. Projection for the Continuous Education or On-the-job Training Needs for the Next 50 Years (100 million):

\begin{tabular}{|l|l|l|l|}
\hline & $\begin{array}{l}\text { Senior high school and } \\
\text { below }\end{array}$ & College and above & Total \\
\hline $2001-2010$ & 2.0 & 0.4 & 2.4 \\
\hline $2011-2020$ & 2.0 & 0.5 & 2.5 \\
\hline $2021-2030$ & 1.8 & 0.9 & 2.7 \\
\hline $2031-2040$ & 1.7 & 1.1 & 2.8 \\
\hline $2041-2050$ & 1.6 & 1.5 & 3.1 \\
\hline
\end{tabular}

Source: MOE: China Education \& Human Resource Report - Stride from a Country of Tremendous

Population to a Country of Profound Human Resources, Part Four, Higher Education Press, Beijing, 2003.

To fulfill such a daunting task, China needs an overall national strategy and policy framework for training and retraining, which should consist of: 1) to strengthen the cooperation and coordination among education, labor, and industry in the provision and financing of training; 2) to overcome the mismatch between skills supply and demand; 3) to provide policies for deregulating private provision and undertaking quality assurance; and 4) to fully unleash the great potential of distance learning, which is very promising considering China's huge geography.

\section{Conclusion}

China stands at a critical point in its overall development, faced with both opportunities and challenges, with severe unemployment being the immediate hurdle. A well-defined strategy would be crucial for China to overcome the challenges and truly become a global player in the $21^{\text {st }}$ century. 
All the strategic thrusts recommended above are highly interrelated and should be considered and implemented in a systemic way, in order to effectively deal with the unprecedented employment challenge in the world's most populous country. Meanwhile, government agencies at all levels, SOEs, private sector, business associations, banks, employment service centers, various reemployment and retraining institutions, labor unions, and all other relevant organizations should be brought together in a concerted and sustained effort. 


\section{References:}

Asia Times. 2002. "Call for More Jobs in China's Service Sector.” April 27, 2002. [http://www.atimes.com].

Bhalla, A. S. and S. Qiu, "China's Accession to WTO: Its Impact on Chinese Employment", UNCTD discussion paper, No. 163, November 2002.

Cai, Fang. 1999. "The Transformation of the Employment Structure in a Dual Labor Market", Social Sciences in China, Vol. 20, No. 3, Autumn.

China Development Gateway. 2002. [http://www.chinagate.com.cn/english/2316.htm]. China Employment Training Center.

China FDI Net. 2003. [http://www.chinafdi.org.cn].

China Internet Information Center. 2001. "Urban Jobless Face Difficulty in Re-employment." [China.org.cn].

China Statistics Bureau \& Ministry of Labor and Social Security. 2002. China Labor Statistical Yearbook. Beijing: China Statistics Press.

China Statistics Bureau. 1999-2002. China Statistical Yearbook. Beijing: China Statistics Press.

China Statistics Bureau. 2003. China Statistical Abstract. Beijing: China Statistics Press.

Chinese Ministry of Education. 2003. China Education \& Human Resource Report - Stride from a Country of Tremendous Population to a Country of Profound Human Resources. Beijing: Higher Education Press.

Chinese Ministry of Labor and Social Security. 2003. China Labor Market website [http://www.lm.gov.cn/gb/content/2002-05/20/content_1383.htm].

Cook, Sarah and S. Jolly. 2000. Unemployment, Poverty and Gender in Urban China: Perceptions and Experiences of Laid Off Workers in Three Chinese Cities, Institute of Development Studies, Sussex, England.

Cook, Sarah. 2000. "Employment, Enterprise and Inequality", from Cook, Sarah, Shujie Yao and J. Zhuang, ed., The Chinese Economy Under Transition, MacMillan (London) and St. Martin's (New York).

Dahlman, C. and J. Aubert. 2001. China \& Knowledge Economy: Seizing the $21^{\text {st }}$ Century. World Bank, Washington, D.C.

De Brauw, Alan. 2002. "The Evolution of China's Rural Labor Markets During the Reforms", Journal of Comparative Economics, V30, pp. 329-353.

Fox, L. and Y. Zhao. 2002. "China's Labor Market Reform: Performance and Prospects." A background study paper for the World Bank, Washington, D.C.

Fruman, C. 2003. "Life-long Learning in China: A Case Study of Shanghai" (internal). World Bank, Washington, D.C.

Gilbert, John and T. Wahl. 2003. "Labor Market Distortions and China's WTO Accession Package: An Applied General Equilibrium Assessment", Journal of Comparative Economics, No. 31, pp. 774-794.

Gill, Indermit, et al. ed. 2000. Vocational Education and Training Reform: Matching Skills to Markets and Budgets, Oxford University Press, New York, N.Y.

Hong Dayong. 2003. "Latest Development of Urban Minimum Living Guarantee System", China Social Development Research Report 2002, Publishing House of People's University.

Hu, Angang. 2001. "China's Employment Problems: Analysis and Solutions", World Economy \& China, V9, No. 1, January/February.

Huang, Fan-Zhang. 2001. "The Current Economic Situation and Trends in China with a Discussion on Employment-related Issues in the Process of Industrialization", from Restructuring Asian Economics for the New Millennium, Volume 9-A, Amsterdam; New York and London: Elsevier Science, JAI.

Hwa, E. C. 2000. "China: Service Sector Development and Competitiveness." Mimeo. World Bank, Washington, D.C. 
Ianchovichina, Elena, W. Martin. 2003. Economic Impacts of China's Accession to the World Trade Organization, World Bank working paper, the World Bank, Washington, D.C.

IFC (International Finance Corporation). 2000. China's Emerging Private Enterprises: Prospects for the New Century. World Bank, Washington, D.C.

IMD (International Institute for Management Development). 2000. The World Competitiveness Yearbook. Lausanne, Switzerland.

Jun, Tang. 2001. "Joining the WTO, the Employment Problem, and How to Deal With It", The Chinese Economy, V34, No. 3.

Knight, John and L. Song. 2003. "Chinese Peasant Choices: Migration, Rural Industry or Farming”, Oxford Development Studies, V31, No.2.

Kung, James L. S. and Y. Lee. 2001 (October). "So What If There is Income Inequality? The Distributive Consequence of Nonfarm Employment in Rural China", Economic Development and Cultural Exchange, V50, No.1.

Lee, Hong Yung. 2000 (November/December). "Xiagang, The Chinese Style of Laying Off Workers", Asian Survey, V40, No. 6.

Lo, V. and X. Tian. 2002. "Property Rights, Productivity Gains and Economic Growth: the Chinese Experience", Post-Communist Economies, V14, No. 2.

Lu, Ming, et al. 2002 (August). "Employment Restructuring during China's Economic Transition", Monty Labor Review, Vol. 125, No. 8.

Meikle, Sheilah and Y. Zhu. 2000. "Employment for Displacees in the Socialist Market Economy of China", from Cernea, Michael M. and C. McDowell ed., Risks and Reconstruction: Experiences of Resettlers and Refugees, the World Bank, Washington, D.C.

Mok, Vincent Wai-kwong. 2002. "Industrial Productivity in China: the Case of the Food Industry in Guangdong Province", Journal of Economic Studies, V29, No.6.

OECD (Organization for Economic Co-operation and Development). 2002. China in the World Economy: the Domestic Policy Challenges. Paris.

OECD. 2000. SME Outlook 2000. Paris.

Pannell, Clifton W. 2002 (September). "China's Continuing Urban Transition”, Environment and Planning, V34, No. 9.

Rawski, Thomas G. 2000. "Economic Growth and Employment in China", from Chai, J. ed., The Economic Development of Modern China, Volume 2, Cheltenham, U.K. and Northampton, Mass.

Rozelle, Scott, Jikun Huang and L. Zhang. 2002. "Emerging Markets, Evolving Institutions, and the New Opportunities for Growth in China's Rural Economy", China Economic Review, V13, pp. 345-353.

Schonleber, Helmut. 2001. "China's Private Economy." Presentation for the DIHT-ACFIC Partnership Project.

Sheehan, Jackie, J. Morris, and J. Hassard. 2000 (July). "Redundancies in Chinese State Enterprises: A Research Report”, Industrial Relations, V39, No. 3.

Solinger, Dorothy J. 2002 (June). "Labor Market Reform and the Plight of the Laid-off Proletariat," The China Quarterly, No. 170.

Tenev, Stoyan and C. Zhang. 2002. "Corporate Governance and Enterprise Reform in China", the World Bank and the International Finance Corporation, Washington, D.C.

Wei, Zuobao, et al. 2003. "The Financial and Operating Performance of China's Newly Privatized Firms", Financial Management, V32, No. 2.

World Bank. 2003a. "Has Training Helped Employ the Xiagang in China? A Tale from Two Cities", East Asia and Pacific Region.

World Bank. 2003b. World Development Indicators 2003. Washington, D.C.

World Bank. 2003c. World Bank SIMA (Statistical Information Management and Analysis) Database. Washington, D.C. 
World Bank. 2003d. China: Promoting Growth with Equity, Country Economic Memorandum, Washington, DC.

Xue, J. \& W. Zhong. 2003. "Unemployment, Poverty and Income Disparity in Urban China", Asian Economic Journal, V17, No. 4.

Yao, Shujie. 1994. Economic Reforms and Grain Production in China, MacMillan, London.

Yao, Shujie. 2000. "Agriculture's Role in Economic Development: The Case of China”, from Cook, Sarah, Shujie Yao and Juzhong Zhuang, ed., "The Chinese Economy Under Transition", MacMillan Press (London) and St. Martin's Press (New York).

Yao, Shujie. 2002. "China's Rural Economy in the First Decade of the $21^{\text {st }}$ Century: Problems and Growth Constraints", China Economic Review, V13, pp. 354-360.

Zhai, Fan, et al. 2002. "WTO Accession, Rural Labor Migration and Urban Unemployment in China", Urban Studies, V39, No. 12,

Zhai, Fan, T. Hertel and Z. Wang. 2003 (May). "Labor Market Distortions, Rural-Urban Inequality and the Opening of China's Economy", GTAP working paper, No. 27.

Zhang, Anming, et al. 2003. "A Study of the R\&D Efficiency and Productivity of Chinese Firms", Journal of Comparative Economics, V31, pp. 444-464.

Zhang, Juwei. 2003. "Urban Xiagang, Unemployment and Policy Support." A background study for the World Bank, Washington, D.C.

Zhang, Linxiu, et al. 2002. "Employment, Emerging Labor Markets, and the Role of Education in Rural China", China Economic Review, V13, No. 2-3.

Zhao, Y. 1996 (June). "Labor Migration and Education in Rural Sichuan Province: A Special Pattern", International Conference on the Flow of Rural Labor in China, Beijing.

Zhao, Y. 2002. "Causes and Consequences of Return Migration: Recent Evidence from China", Journal of Comparative Economics, V30, pp. 376-394. 